\title{
OBRONA KULTU OBRAZÓW W TRZECH MOWACH APOLOGETYCZNYCH PRZECIWKO TYM, KTÓRZY ODRZUCAJĄ ŚWIĘTE OBRAZY ŚW. JANA DAMASCEŃSKIEGO
}

W kulcie obrazów głoszone przez Kościół prawdy wiary (ius credendi), sformułowane w specyficznym języku teologii, aktualizują się wyrażone językiem liturgii bądź prywatnej ludzkiej pobożności. Nierzadko obcy współczesnej mentalności dogmat staje się w ten sposób konkretną, zbawczą rzeczywistością, którą żyje zarówno poszczególny chrześcijanin, jak i cała wspólnota kościelna (ius orandi). Jednym ze zdecydowanych obrońców wartości obrazu jako obiektu kultu oraz medium, za pomocą którego możliwe jest nawiązanie prawdziwej relacji z Bogiem, jest św. Jan Damasceński, świadek dramatycznych wydarzeń, określanych dziś jako okres pierwszego ikonoklazmu (726-787). Swoje stanowisko w kwestii kultu obrazów Damasceńczyk najpełniej wyraził w Trzech mowach apologetycznych przeciwko tym, którzy odrzucaja święte obrazy. Należą one do wczesnego etapu apologii wykuwanego, można by rzec, na bieżąco, w reakcji na wydarzenia zachodzące w Cesarstwie Bizantyńskim.

W pierwszej kolejności zaprezentuję tu próbę zdefiniowania przez Damasceńczyka samego kultu obrazów oraz wyróżnienia poszczególnych jego rodzajów. Następnie przedstawię zasadnicze pola konfliktów, w jakie angażował się nasz autor i w których argumentował na rzecz obrazów. Istotny wydaje się tu zwłaszcza argument z wcielenia, wykorzystywany przez Jana w polemice ze starotestamentowym zakazem czynienia obrazów. Zobaczymy również, w jaki sposób Damasceńczyk odróżnia właściwy kult obrazów od kultu idolatrycznego oraz jego związek z kultem świętych, a także, jak wiąże on kwestię wolności kultu ikon z problemem wolności Kościoła i jego relacji do państwa. Na koniec przyjrzę się kwestii bardziej metodologicznej, 
tzn. sposobowi, w jaki Jan Damasceński odnosił się do tradycji niepisanej oraz pism Ojców Kościoła, i jak wykorzystywał ten materiał w swojej apologii. ${ }^{1}$

\section{Definicja i rodzaje kultu}

Pojęcie kultu Jan Damasceński definiuje w dwu miejscach: w mowie pierwszej oraz trzeciej. W obydwu przypadkach mamy do czynienia ze zwięzłymi charakterystykami. Pierwsza definicja brzmi następująco: „Oddawanie czci jest znakiem okazywania uniżenia i szacunku”. ${ }^{2}$ Druga jest analogiczna: „Kult jest znakiem podporządkowania; z podporządkowania wynika zaś umniejszenie i upokorzenie". ${ }^{3}$ Należy tu zwrócić uwagę na dwa zasadnicze elementy: zewnętrzny - znak, czyli taki gest lub sposób zachowania, który uzewnętrznia drugi element, wewnętrzny - moralną postawę wobec przedmiotu kultu - przy czym wszystkie wymienione tu postawy: uniżenia, szacunku, podporządkowania mają charakter relacji osobowej. Taką personalną interpretację, zgodnie z sugestiami Th. Siderisa, ${ }^{4}$ potwierdza, wspomniany już przez nas, a przytoczony przez Damasceńczyka, cytat ze św. Bazylego: „Cześć oddana obrazowi przechodzi na jego prototyp" obrazie, ale dotyka wyobrażonej na nim osoby.

1 Obecnie na język polski przetłumaczono tylko pierwszą Mowę św. Jana: Św. J a n D a ma s c eń s k i, I. mowa obronna przeciw tym, którzy odrzucaja święte obrazy (Contra imaginum calumniatores I), tłum. M. D y le w s k a, Vox Patrum 36-37(1999) 19, s. 497-515 i z tego tłumaczenia korzystałem. W pozostałych przypadkach opierałem się na wydaniu J.P. M ig n e 'a: PG 94, 1232-1220 oraz angielskim tłumaczeniu: St. J o h n of D a m a s c u s, On the Divine Image, tłum.

D. A n d e r s o n, New York 1980.

2 I,14 (PG 94, 1244AB).

3 III,27 (PG 94, 1348D).

4 Por. Th. Sideris, The Theological Position of the Iconofiles during the Iconoclastic Controversy, St. Vladimir Seminary Quarterly 17/1973, s. 213-214.

5 I,21.35 (PG 94, 1252B1253D.1261D-1264A); S. B a s i 1 i, De Spir.18,45, PG 32, 149C; Św. B a z y li, O Duchu Świętym, tłum. A. B r z ó s t k o w s k a, Warszawa 1999, s. 146. 
Autor wymienia następnie poszczególne rodzaje kultu. W mowie pierwszej wymienia trzy kategorie. „Najpierw istnieje uwielbienie ( $\lambda \alpha \tau \rho \varepsilon i ́ \alpha)$, jakie winniśmy samemu Bogu, który ze względu na swą naturę sam godzien jest chwały. Następnie ze względu na (...) Boga, składamy cześć ( $\pi \rho 0 \sigma \kappa v ́ v \eta \sigma ı)$ ) Jego przyjaciołom i sługom”. ${ }^{6}$ Przypomina tu m.in. cześć, jaką Jozue oddawał aniołowi, a Dawid czcił „Boże miejsca” (por. Ps 132, 7). „Istnieje także cześć ( $\pi \rho 0 \sigma \kappa v ́ v \eta \sigma ı \varsigma)$, jaką składa się ze względu na wyjątkowy szacunek względem innych, tak jak wyraził go Abraham wobec synów Chamora"?

Bardziej rozbudowana jest klasyfikacja czci w mowie trzeciej. ${ }^{8}$ $\mathrm{Na}$ pierwszym miejscu autor wymienia rodzaj czci bezwzględnej ( $\lambda \alpha \tau \rho \varepsilon i ́ \alpha)$, która należy się tylko jedynemu Bogu. Wyraża się ją na pięć różnych sposobów. Pierwszy porównywalny jest do czci oddawanej przez poddanych swojemu Panu. Oddają ją wszystkie stworzenia, jedne - jak ludzie pobożni - dobrowolnie, inne - jak złe duchy - nawet wbrew swojej woli, jeszcze inne czczą Go z natury, nawet Go nie znając. Drugi sposób obejmuje bojaźń i tęsknotę wobec Boga z racji chwały, którą ma z natury: „Tylko On jest otoczony chwałą, nie otrzymując jej od kogokolwiek, lecz samemu będąc przyczyną jakiejkolwiek chwały". ${ }^{9}$ Trzecim sposobem jest dziękczynienie za dobra, które zostały dla nas stworzone, ,ponieważ wszystkie rzeczy od Niego mają byt (por. Rz 11,36) i w Nim istnieją (por. Kol 1,17) i bez nienawiści udziela On ze swych darów wszystkim (por. Mdr 7,13)". ${ }^{10}$ Kolejny sposób inspirowany jest przez nasze potrzeby i nadzieje na Jego błogosławieństwo. Czcimy Go, gdy prosimy o to, co jest każdemu z nas potrzebne, a wreszcie, abyśmy zostali uwolnieni od zła i osiągnęli dobro. Ostatni, piąty, sposób czci bezwzględnej to skrucha i wyznanie grzechów. Tu znowu Jan dokonuje podziału. Prosimy Boga o odpuszczenie grzechów z trojakiego powodu: albo z powodu

\footnotetext{
I,14 (PG 94, 1244AB).

I,14 (PG 94, 1244AB).

Por. III, 27-40 (PG 94, 1348D-1356C).

III,29 (PG 94, 1349AB).

III,30 (PG 94, 1349BC).
} 
miłości do Niego samego, czyli z pobudek synowskich, albo z powodu lęku, przed nieotrzymaniem dóbr, którymi dysponuje, na zasadzie najemnika, albo też z lęku przed karą, czyli z pobudek niewolniczych. ${ }^{11}$

Oprócz czci należnej tylko Bogu, Jan mówi o czci względnej ( $\pi \rho \circ \sigma \kappa v ́ v \eta \sigma ı \varsigma)$, która należy się przede wszystkim tym, którzy

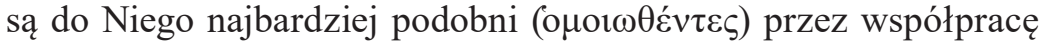

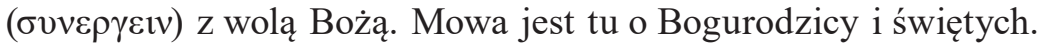
Autor przyznaje, że jedynym prawdziwie świętym jest Bóg, ale i ci, w których zamieszkał, nazywani są bogami (por. Ps 82,6), dlatego godni są czci. „A więc my oddajemy im cześć, ponieważ król jest obdarzony czcią, kiedy widzi, że sługa przez niego miłowany jest czczony - nie jako król, lecz jako posłuszny sługa i miłujący przyjaciel". ${ }^{12}$

Na drugim miejscu Jan wymienia cześć oddawaną rzeczom, przez które Bóg dokonał naszego zbawienia zarówno przed przyjściem naszego Pana, jak i podczas ekonomii Jego wcielenia. Damasceńczyk wymienia tutaj: Górę Synaj, miasto Nazaret, żłóbek i grotę w Betlejem, Golgotę, drzewo krzyża, gwoździe, trzcinę i włócznie, płaszcz, prześcieradła, którymi owinięte było ciało Chrystusa, grób święty i wiele innych miejsc i przedmiotów. ${ }^{13}$

Trzeci rodzaj kultu dotyczy rzeczy poświęconych Bogu, tj. Ewangelii i innych ksiąg, naczyń liturgicznych, kadzideł, świeczników i tablic..$^{14}$

Czwarty dotyczy obrazów, które autor wymieniał w swoich hierarchiach jako prefiguracje, czyli obrazy alegoryczne oraz obrazy rzeczy przeszłych. ${ }^{15}$

Piąty rodzaj czci, to ten, który jedni oddają drugim, jako tym, którzy są dziedzicami Boga (por. 2P 1,4) i zostali stworzeni na Jego

11 To rozróżnienie nawiązuje bezpośrednio do św. B a z y l e g o W i e 1 k i e g o, Regulae fusius tractatae 3, PG 31, 896B.

12 III, 33 (PG 94, 1352CD).

13 Por. III, 34 (PG 94, 1353AC).

14 Por. III, 35 (PG 94, 1353CD).

15 Por. III, 36 (PG 94, 1353D-1356A). 
obraz (por. Rdz 1,26). Jesteśmy więc poddani jedni drugim, wypełniając prawo miłości (por. Ef 5,21). ${ }^{16}$

Dalej autor wymienia oddawanie czci należnej tym, którzy sprawują władzę, a na ostatnim, siódmym, miejscu umieszcza szacunek, który słudzy oddają panom, a ludzie znajdujący się w potrzebie zaś swoim dobroczyńcom. ${ }^{17}$

Obydwie przedstawione wyżej klasyfikacje opierają się na za-

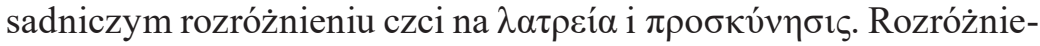
nie to sięga w przeszłość aż Orygenesa: „Co innego znaczy «czcić»

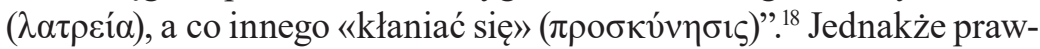
dopodobnie ma ono pochodzenie pozachrześcijańskie. Mogło powstać w kontekście kultu cesarzy rzymskich, gdzie odróżniano między dwoma rodzajami wizerunków: zwykłymi obrazami, umieszczanymi w miejscach publicznych, a posągami kultycznymi, umieszczanymi w świątyniach. Podział ten został zaaprobowany przez chrześcijan w trakcie formowania się obrony własnego kultu obrazów. Jednak Jan ma w tym swój niewątpliwy udział, gdyż jako pierwszy użył tego rozróżnienia w nowym kontekście. ${ }^{19}$

16 Por. III, 37 (PG 94, 1356B).

17 Por. III, 38 (PG 94, 1356B).

18 O r y ge n e s, Homila 8. O początku Dekalogu 4, w: t e n ż e, Homilie o Księgach Rodzaju, Wyjścia, Kapłańskiej, tłum. S. K a 1 i n o w s k i, Pisma Starochrześcijańskich Pisarzy, t. XXXI, z. 1, Warszawa 1984, s. 226; por. O r i g e n i s, In Exodus homilia VIII, 4, PG 12, 354BC.

19 Por. K. P a r r y, Depicting the World: Byzantine iconophile though of the eighth and ninth centuries, Leiden-New York-Köln 1996, s. 166. Trzeba również zwrócić uwagę, że mówienie o kulcie obrazów napotyka pewne trudności natury lingwistycznej. Chodzi o przekład greckich terminów latreia i proskynesis. Problem ten dotyczy języka polskiego, ale także innych języków współczesnych. Th. Sideris skarży się na trudności z przekładem tych pojęć na język angielski. W angielskim obydwa te terminy można wyrazić za pomocą jednego słowa worship, które oznacza uwielbienie, kult, cześć, przez co zaciemnia doniosłość tego rozróżnienia. Z podobną trudnością spotykamy się również w języku polskim. Tymczasem greckie słowo latreia wyraża pełnię boskiej czci, która oddawana jest tylko Bogu, zaś słowo proskynesis wyraża orientalny z pochodzenia akt prostracji, czołobitności, który oddawany jest nie tylko Bogu, ale także osobom i przedmiotom świętym, 


\section{Zakaz tworzenia wizerunków a wcielenie Boga}

Najstarszym powodem sprzeciwu wobec tworzenia i kultu obrazów świętych, z jakim zmuszony był polemizować Jan Damasceński, był zakaz znajdujący się na kartach Starego Testamentu. Argument ten był szczególnie żywotny podczas tzw. pierwszego ikonoklazmu, kiedy to Jan Damasceński pisał swoje mowy, dlatego poświęca temu problemowi bardzo dużo miejsca.

Fundamentalnym w tym kontekście tekstem jest Wj 20,3-4: „Nie będziesz czcił obcych bogów, nie zrobisz żadnego wizerunku jakiegokolwiek ptaka latającego wysoko na niebie, ani jakiegokolwiek zwierzęcia, które jest nisko na ziemi". ${ }^{20}$ Aby wesprzeć argumentację ikonoklastów, Damasceńczyk dodaje do tego zakazu kolejne cytaty ze Starego Testamentu: „Pan Bóg twój jest Panem jedynym” (Pwt 6,4), „Panu Bogu twojemu będziesz cześć oddawał i Jego samego będziesz uwielbiał” (Pwt 6,13) oraz „Zawstydzeni zostaną wszyscy, którzy hołd składają rzeźbom i wizerunkom" (Ps 97,7). ${ }^{21}$

Autor wydaje się przyznawać rację swoim adwersarzom, jednak okazuje się to tylko środkiem retorycznym, gdyż zaraz potem zarzuca $\mathrm{im}$, że w istocie nie rozumieją Starego Testamentu i dają posłuch złemu: „Wstydź się nikczemny diable, zniechęcający nas do oglądania podobizny naszego Mistrza i świętości, która z niej bije. (...) Jesteś zazdrosny o cześć, jaką Bóg otrzymuje od swoich świętych”. ${ }^{22}$ Damasceńczyk twierdzi, że mylą się ci, którzy interpretują słowa Pisma Świętego literalnie. Powołuje się tu na 2Kor 3,6: „Litera zabija,

jako wyrażenie należnego szacunku; por. Th. S i d e r i s, The Theological Position of the Iconophiles, s. 217. Polski termin „cześć”, aby był odpowiednio zrozumiany, wymaga zawsze doprecyzowania. Problem ten zaważył na losach kultu obrazów na Zachodzie, gdyż obydwa greckie terminy oddawano za pomocą jednego łacińskiego słowa adoratio. W następstwie prowadziło to do wielu nieporozumień - a zwłaszcza wieloletnich trudności z uznaniem ekumeniczności II Soboru Nicejskiego; por. K. P a r r y, Depicting the World, s. 206.

20 I,4 (PG 94, 1233D-1236C).

21 Tamże.

22 II,6 (PG 94, 1288BC); por. też III,13 (PG 94, 1241D-1244A) . 
a duch ożywia”. Ci bowiem, którzy nie rozpoznają ducha Pisma, nie są w stanie poznać jego właściwego sensu. ${ }^{23}$ Zdaniem Jana, aby zrozumieć pisma, należy je badać ze szczególną wnikliwością. Zwraca uwagę, że ten sam prawodawca - Bóg - zdecydowanie zakazując kultu wszelkich wizerunków, z taką samą mocą domaga się od Mojżesza wykonania wizerunków, którym oddawana będzie nabożna cześć. „Jak to wyjaśnisz, Mojżeszu? Z jednej strony mówisz: «Nie będziesz sobie czynił żadnej rzeźby ani podobizny», ale sam każesz, żeby zasłona była utkana w cherubiny, a dwa cherubiny zostają ulane ze szczerego złota". ${ }^{4}$ Podobnie Bóg domaga się od niego stworzenia Arki Przymierza, Namiotu Spotkania, miedzianego węża i wielu inny znaków. ${ }^{25}$

Tego typu przypadki tylko z pozoru wyrażają niekonsekwencję starotestamentowego Prawa. Pokazują one raczej, że zakaz nie ma charakteru bezwzględnego. Prawo staje się w pełni spójne i zrozumiałe, jeśli spojrzy się na nie z punktu widzenia Bożej ekonomii i celu, dla którego powstało. Jan porównuje Boga, dawcę Prawa zarówno Starego, jak i Nowego Testamentu, do dobrego lekarza, który nie przepisuje tego samego lekarstwa dla wszystkich pacjentów, ale uzależnia go od ich potrzeb, bierze pod uwagę rodzaj choroby, klimat, porę roku, wiek, a za Hbr 1,1 powtarza, że Bóg „mówił wcześniej na wiele różnych sposobów do naszych ojców przez proroków, a w tych dniach ostatecznych przemówił przez swojego Syna Jednorodzonego". ${ }^{26}$

Co zatem jest celem owego Prawa, co jest „chorobą”, którą ma uleczyć i jak to Prawo w ogólności, a zakaz czynienia obrazów szczególnie, ma się do faktu przyjścia „w tych dniach ostatecznych” na świat Jednorodzonego Syna - Jezusa Chrystusa?

Na pytanie o cel Prawa w sposób jednoznaczny odpowiada ono samo. Pwt 5,7 mówi: „...nie będziesz miał bogów cudzych przede

\footnotetext{
23 Por. I,5 (PG 94, 1236D-1237A).

24 II,9 (PG 94, 1292C-1293A); por. też. I,15 (PG 94, 1244C-1245A).

25 Por. I,15.

${ }^{26}$ I,4 (PG 94, 1233D-1236C) oraz II,7 (PG 94, 1288-1289).
} 
Mną. (...) ponieważ Ja jestem Pan, Bóg wasz”. Jan Damasceński, opierając się na tym tekście a także Pwt 12,3 i Wj 34,17, formułuje ów cel następująco: „Nie czcić stworzenia ponad Stwórcę i nie uwielbiać nikogo, z wyjątkiem samego Stwórcy". ${ }^{27}$ Tak więc celem Prawa jest chronienie przed bałwochwalstwem, gdyż ono właśnie było chorobą trawiącą naród wybrany. Jan przytacza spektakularny przykład z Księgi Wyjścia. Podczas gdy Mojżesz przebywał na Górze Synaj, gdzie otrzymał tablice z dziesięciorgiem przykazań, synowie Izraela zwrócili się do Aarona, aby pozwolił im ulać z zebranych kosztowności złotego cielca. Następnie świętowali i żenili się, wskazując na cielca jako swojego boga (Wj 32,1nn.). „Nie widzisz, że oni czcili idoli, którzy są mieszkaniami demonów, jako bogów, i że adorowali stworzenia zamiast Stworzyciela?" 28 - pyta retorycznie Damasceńczyk.

Jan Damasceński zdecydowanie twierdzi, że starotestamentowe Prawo nie obowiązuje już w dzisiejszej sytuacji. Zakaz tworzenia obrazów został dany Żydom ze względu na ich skłonność do idolatrii, podczas gdy chrześcijanie wolni są od tego zagrożenia. Za Grzegorzem z Nazjanzu ${ }^{29}$ zapewnia, że chrześcijanie nie są podatni na tę ,chorobę”, ponieważ dane im było poznać prawdę, dzięki której stali się w pełni dojrzałymi ludźmi, potrafiącymi wielbić jedynego Boga zgodnie z ortodoksją. ,Skoro zaś otrzymaliśmy od Boga zdolność rozróżniania i wiedzę, co można przedstawiać jako wizerunek, a czego przedstawiać nie należy, nie potrzebujemy już więcej pozostawać pod opieką wychowawcy"30 - wychowawcy, którym jest Prawo.

Obowiązywalność Prawa utraciła jeszcze jedną legitymację. Prawo zabezpieczało przed naruszeniem absolutnej transcendencji Boga. Dopóki Bóg nie objawił swojej postaci, wykluczona była możliwość tworzenia Jego prawdziwego wizerunku, który nie uwłaczałby

27 I,6(PG 94, 1237B); por. też I,15.

28 II,8(PG 94, 1289C-1292C).

29 Por. S. G re g or i i T h e ol o g i i, Oratio 39, 8 PG 36, 341D-344A; Św. G r z e gorz z Nazjanzu, Mowy wybrane, tłum. K. Kazikowski i in., Warszawa 1967, s. 428.

30 I,8 (PG 94, 1237C-1240B). 
Jego bóstwu. Na potwierdzenie tej tezy Damasceńczyk wielokrotnie przytacza biblijne teksty: „...pilnie się wystrzegajcie, skoro nie widzieliście postaci w tym dniu, w którym przemówił do was Pan na Górze Horeb spośród ognia, byście nie przekroczyli Prawa i nie uczynili sobie rzeźbionego wizerunku, ani jakiegokolwiek obrazu przedstawiającego mężczyznę czy kobietę, podobiznę jakiegokolwiek zwierzęcia na ziemi, podobiznę jakiegokolwiek ptaka..." (Pwt 4,15) i analogiczne do niego Pwt 4,12 i Wj 33,20, a z Nowego Testamentu J1,18 oraz Dz 17,29. ${ }^{31}$ Autor przyznaje, że gdyby ikonofile chcieli tworzyć obrazy niewidzialnego Boga, to można by im rzeczywiście zarzucić winę. Nie jest jednak błędem przedstawianie Boga, który stał się widzialny. „Skoro bowiem wiadomo, że Ten, który z natury jest niewidzialny, stał się widzialny pod postacią ciała, tedy można sporządzić obraz tego, co widzialne" 32 .

Jan Damasceński dochodzi w ten sposób do kulminacyjnego punktu swojej argumentacji na rzecz obrony obrazów, którym jest wcielenie Boga - prawda, stanowiąca podstawowy dogmat wiary chrześcijańskiej. Wychodzi tym samym poza kanon tradycyjnej argumentacji stosowanej w polemikach w okresie przed ogłoszeniem Zapytań (Peuseis) Konstantyna $\mathrm{V}^{33}$ - niejako je antycypuje, choć nie rozwiewa wątpliwości, które formułuje później cesarz.

Bóg, który za sprawą unii hipostatycznej staje się widzialny w ludzkiej postaci, niweczy całkowicie zakazy starego Prawa odnoszące się

31 Por. I,5 (PG 94, 1236D-1237A).

32 I,8 (PG 94, 1237C-1240B); por. II, 5 (PG 94, 1288AB).

33 Peuseis Konstantego V są znane tylko we fragmentach z dwóch pierwszych Antirrhetikoi Nicefora, PG 100, 206-373. Dodajmy, że ważnym punktem odniesienia jest krótka praca Hypatiusza z Efezu $O$ kulcie obrazów będąca świadectwem wczesnych polemik w VI w. Stanowi ona pierwszą poważną dyskusję na temat tworzenia i kultu obrazów. Autor odnosi się w niej do starotestamentowego zakazu, natomiast w żadnym zakresie nie posługuje się argumentami chrystologicznymi; F. D i e k a m p, Hypatius von Ephesus, w: Analecta patristica, Orientalia Christiana Analecta 117, Roma 1938, s. 109-153; H y p a t i u s z z E fe z u, O kulcie obrazów (Symmikta dzetemata I 5), wstęp i tłum. J. N a u m o w i c z, Vox Patrum 11-12 (1991-1992) z. 20-23, s. 429-435. 
do kwestii wizerunków. Autor dowodzi nawet, że Bóg sam wskazuje na tymczasowość zakazu, gdy w Ez 20,25 twierdzi, że ze względu na zatwardziałość serc Izraelczyków dopuścił prawa i zakazy, które nie były dla nich dobre. ${ }^{34}$ Powołując się na słowa Jezusa, Damasceńczyk sugeruje, że to sam Bóg pragnie, aby Go oglądano: „A to jest życie wieczne, aby znali Ciebie, jedynego prawdziwego Boga, oraz Tego, którego posłałeś, Jezusa Chrystusa” $(\mathrm{J} 17,3)^{35}$ oraz: „Wielu proroków i sprawiedliwych pragnęło ujrzeć to, na co wy patrzycie, a nie ujrzeli; i usłyszeć to, co wy słyszycie, a nie usłyszeli. Lecz szczęśliwe oczy wasze, że widzą, i uszy wasze, że słyszą" (Mt 13,17.16). Jan wnioskuje zatem, że choć współcześni widzieli Chrystusa twarzą w twarz, to równie szczęśliwi są ci, którzy mogą czytać Jego słowa zapisane w księgach i wchodzić w intymną relację, kontemplując wizerunek Jego cielesnej postaci przez malowidła. ${ }^{36}$

Jan Damasceński, mimo że konsekwentnie opowiada się po stronie tworzenia świętych obrazów, bynajmniej nie zaprzecza prawdziwości teologii negatywnej - apofatycznej, która z natury rzeczy wspiera argumentację ikonoklastów. Przeciwnie, postawa proikoniczna nie przeszkadza mu, paradoksalnie, być wyrazicielem apofatyzmu. Czyni to, idąc za Dionizym Areopagitą, który pisze: „Istnieją też intelekty o boskim kształcie, które - na ile to jest możliwe - łączą się wzorem aniołów z jednością wtedy, gdy zrzekają się wszelkiej energii intelektualnej i wchodzą w związek ze światłością ponadboską, najodpowiedniej głosząc chwałę Boga przez negację wszystkiego, co istnieje". ${ }^{37} \mathrm{~W}$ tym fragmencie, zdaniem K. Parry'ego, Areopagita łączy dwie doktryny: apofatyczną i przebóstwienia, tworząc fundament

34 II,15 (PG 94, 1244C-1245A).

35 I,4 (PG 94, 1233D-1236C).

36 Por. III,12 (PG 94, 1334D-1336B); por. N. G e $\mathrm{n} \mathrm{d} \mathrm{l}$ e, Creation and Incarnation in the Iconology of St. John of Damascus, w: G.D. D r a g a s (red.) Acsum, Thyateira. A Festschrift for Archibishop Methodios of Thyateira and Great Britain, London 1985, s. 644.

${ }_{37}$ P s e udo-Dionizy A re opag it a, Pisma teologiczne, tłum. M. Zi e ls k a, Kraków 1997, s. 53; S. D i o n is i i A r e o pag i t a e, De divinis nominibus 1,5 PG 3, 593C. 
teologii mistycznej. Światłość, o której pisze Dionizy, domaga się bowiem z jednej strony ujęcia całościowego za pomocą środków wyrazu dostępnych człowiekowi, z drugiej zaś uczestnictwa, czyli przebóstwienia. ${ }^{38}$ Według św. Maksyma Wyznawcy, szczyt poznania Boga osiąga się w ciszy, która pochodzi z prawdziwej niewiedzy. ${ }^{39}$ Także Grzegorz z Nyssy zwraca uwagę na nieadekwatność środków ludzkiej mowy do wyrażania rzeczywistości, która transcenduje nawet wszelkie myślenie. ${ }^{40}$

W perspektywie zagadnienia całościowego ujęcia owej „ponadboskiej” rzeczywistości, ważnym problemem staje się kwestia języka, który służy do wyrażenia tejże transcendencji.

W niezwykłym credo, które Damasceńczyk umieścił na początku swojej pierwszej mowy, autor opisuje Boga, używając następujących

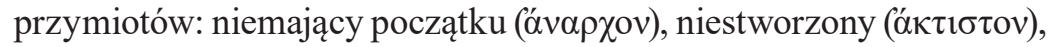

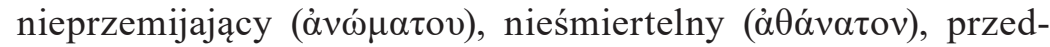

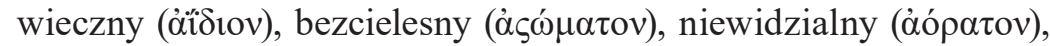

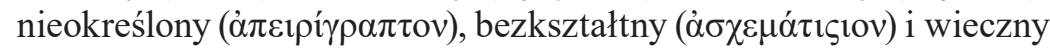

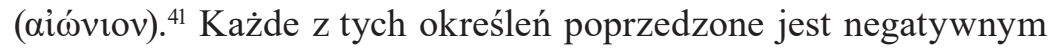
przedrostkiem $\alpha$-. Alfa prywatywne, które odpowiada polskiemu „nie-” lub „bez-”, jest zwykłym sposobem negacji w grece. ${ }^{42} \mathrm{Nie}$ mamy jednak $w$ tym przypadku do czynienia z prostym faktem zanegowania Bożej egzystencji. Wyraża ona raczej inny, wznioślejszy sposób istnienia Boga. W pismach Jana Damasceńskiego obok określeń negatywnych pojawiają się bowiem w odniesieniu do bóstwa również określenia afirmatywne, takie jak ,istnienie”, „substancja”, ,życie”,

38 Por. K. P a r r y, Depicting the World, s. 114

39 Por. Maks y m Wy z n aw c a, The Philokalia. The complet text, tłum. G.E.H. P a $1 \mathrm{~m}$ e $\mathrm{r}$ i in., London-Boston 1981, t. II, s. 99.

40 Por. S. G r e g or i i N y s s e n i, In Ecclesiasten. Homilia 7, PG 44, 724D-732D.

${ }_{41}$ Por. I,4.7-8 (PG 94, 1233D-1236C.1237C-1240B); II,7-8 (PG 94,1288D-1292C).

42 Warto zwrócić uwagę na dwa sposoby wyrażania negacji w mówieniu o Bogu, albo za pomocą zdania twierdzącego, w którym orzeczenik poprzedzony jest przez alfa prywatywne, wtedy mówi się np. „Bóg jest niezniszczalny” albo przez zdanie negatywne, w którym negacja odnosi się do łącznika podmiotu imiennego, wtedy zdanie brzmi „Bóg nie jest zniszczalny”. 
„siła” ${ }^{43}$ Skoro jednak natura Boga nie egzystuje tak, jak inne byty, lecz wszystkie je transcenduje, zupełnie nie przystaje do umysłu ludzkiego. Poprawniej jest zatem mówić o Nim, kim „nie-” jest, niż jest. Ludzki język okazuje się zupełnie nieodpowiedni, aby wyczerpywać Boską naturę. Choć obydwie doktryny, apofatyczna i katafatyczna, są równie ważne i jedna nie może być używana bez drugiej, to ostatecznie poznanie Boga jest możliwe tylko poza wszelką spekulacją. ${ }^{44}$

Relacja między apofatyzmem a twórczością religijną włączona została w dyskusję dotyczącą natury Chrystusa. Głównym problemem stało się to, co tak naprawdę przedstawiają nam Jego ikony. Skoro Bóg jest z natury niewidzialny i bezkształtny, to co przedstawia ikona Chrystusa, który jest nie tylko Bogiem, ale i człowiekiem? Problem ten, jako pierwszy, postawił przeciwnik obrazów - cesarz Konstantyn V.

Według Jana Damasceńskiego, obraz bez wcielenia jest niemożliwy. „Któż jest w stanie odsłonić to, co jest tajemnicą? Jasne jest jednak, że skoro widzisz Tego, który, z natury bezcielesny, ze względu na ciebie stał się człowiekiem, to możesz wykonać wizerunek jego ludzkiej postaci". ${ }^{45}$ Nie znaczy to jednak, że przez wcielenie zostaje umniejszona boskość Chrystusa. Przeciwnie, stał się On człowiekiem, aby podnieść naszą ludzką naturę i uczynić nas uczestnikami Boskiej natury: „... sławię Stwórcę, który sam stał się stworzeniem takim, jak ja i w stworzenie ubrany bez uszczerbku swej boskiej natury uczcił w ten sposób moją własną ludzką naturę, czyniąc mnie tym samym uczestnikiem swojego bóstwa". ${ }^{46}$ Od kiedy Słowo stało się ciałem,

43 Por. S. Jo a n n is D a m a s c e n i, De fide orthodoxa I, 12-13 (PG 94, 844C-860A). Jan sugeruje tam także, że najodpowiedniejsze na określenie Boga są terminy zawierające zarówno negację, jak i afirmację, jak hyperoúsios ousía (superessentialis essentia) - istota ponad wszelką istotę, hypértheos theótes (superdivina Deitas) - nadboskie Bóstwo; por. Św. J a n D a m a s c é s k i, Wykład Wiary Prawdziwej, tłum. B. W o j k o w s k i, Warszawa 1969, s. 51-60; por. także K. P a r r y, Depicting the World, s. 116.

44 Por. tamże.

45 I,9 (PG 94, 1240C).

46 I,4 (PG 94, 1233D-1236C). 
ludzka natura stała się naturą Słowa, Jego hipostazą. Można zatem tworzyć obrazy Boga, nie jako niewidzialnego, ale jako tego, który ze względu na nas stał się widzialny, przez uczestnictwo we krwi i ciele. ${ }^{47}$

Jan bazuje w swojej argumentacji na rzecz obrazów Chrystusa nie na samym fakcie, że Bóg stał się człowiekiem, ale na tym, że będąc Bogiem, zachował jednocześnie nienaruszoną ludzką naturę. „Przecież (...) ciało Boga jest Bogiem tylko ze względu na zaistniałe niezmienne hipostatyczne zjednoczenie. Ciało to (...) pozostaje zgodnie z naturą obdarzone rozumną i myślącą duszą, ma początek i nie jest odwieczne". ${ }^{48}$ Jan jest tutaj zgodny z nauką Soboru Chalcedońskiego, który głosi, że należy wyznawać Chrystusa „w dwóch naturach: bez zmieszania, bez zmiany, bez podzielenia i rozłączenia". ${ }^{49}$ Ta nauka, którą posługuje się Damasceńczyk, jest ważnym argumentem na rzecz twórców obrazów przedstawiających Chrystusa po Jego zmartwychwstaniu i wniebowstąpieniu. Ikonoklaści bowiem, w tym cesarz Konstantyn V, zarzucali ikonom, że przedstawiają postać Zbawiciela w Jego przemijalnej a nie obecnej postaci, gdy zasiada uwielbiony po prawicy Ojca. ${ }^{50}$

Należy stwierdzić, że wypowiedź Jana w kontekście zarzutów stawianych przez Konstantyna nie może być jednak uznana za w pełni satysfakcjonującą. Cesarz twierdzi bowiem, że niemożliwe jest przedstawienie w obrazie dwóch natur zjednoczonych w jednej osobie (prosopon) Chrystusa, z których jedna w ogóle nie daje się opisać. Artysta zatem z konieczności albo je rozdziela, albo miesza ze sobą, popadając $\mathrm{w}$ nestorianizm lub też $\mathrm{w}$ monofizytyzm. ${ }^{51}$

47 Por. tamże.

48 I,16 (PG 94, 1245A-1248B).

49 S obór Chalcedoń s k i (451), Definicja wiary 11, w: A. B a r o n, H. P i e tr a s (oprac.), Dokumenty Soborów Powszechnych, t. I, Kraków 2001-2007, s. 22 (dalej: DSP), 3; S. G ł o w a, I. B i e d a (oprac.), Breviarium fidei. Wybór doktrynalnych wypowiedzi Kościoła, Poznań 1998, VI, 8 (dalej: BF).

50 Por. K. P a r r y, Depicting the World, s. 72.

${ }_{51}$ Por. Th. S i d e r i s, The Theologiccal Argument of the Iconoclasts During The Iconoc-lastic Controversy, Bizantine studies /Aetudes Byzantines 1-2 (1979) 6, s. 183-185. 
Przeprowadzona przez Jana Damasceńskiego obrona obrazów nie potrafiła w tym punkcie stanąć na wysokości zadania, ponieważ miała zdecydowanie za mało relacyjny charakter. Mimo że badacze odnajdują u Damasceńczyka ślady takiego sposobu rozumowania, ${ }^{52}$ ostatecznie jednak jego myśl oscyluje cały czas wokół platońskiej koncepcji uczestnictwa, czego konsekwencją jest przyznanie jakiegoś stopnia istotowej tożsamości między obrazem a jego prototypem. ${ }^{53}$ W tym kontekście nie sposób rozwikłać paradoksu, który przedstawia Konstantyn V.

Nic zatem dziwnego, że Jan skierował swoją refleksję w innym kierunku. Otóż, wychodząc z przesłanek chrystologicznych, podkreślał pozytywną rolę materii, a tych, którzy odrzucali kult obrazów ze względu na ich materialność, nazywał po prostu manichejczykami. „Nie pogardzaj (...) materią, gdyż nie jest ona godna pogardy. Żadnej z rzeczy, która pochodzi od Boga nie należy się wzgarda. Byłoby to myślenie manichejczyków". ${ }^{54}$ Po wcieleniu Boga status materii, jego zdaniem, zmienił się diametralnie. Stała się ona narzędziem zbawienia i naczyniem napełnionym ,boską energią i łaską". ${ }^{55}$ Choć upadła niegdyś, teraz została zrehabilitowana. ,...cała natura odzyskała pierwotny stan szczęśliwości; (...) wydźwignęła się z najniższych pokładów ziemi ponad to wszystko, co było na początku i zasiadła na tronie swojego Ojca". ${ }^{56}$

Jan Damasceński bardzo silnie podkreśla zbawczy skutek wcielenia. Materia ukazuje w ten sposób swój charakter sakramentalny. ${ }^{57}$ „Nie składam hołdu materii, ale oddaję cześć jej Stwórcy, który ze względu na mnie (...) zgodził się zamieszkać wśród materialnego świata i poprzez tę właśnie materię dokonał mojego zbawienia. Nie przestanę zatem czcić materii, przez którą dokonało się moje

52 Por. K. P a r r y, Depicting the World, s. 26-27; Th. S i d e r i s, The Teological Position, s. 213-214.

53 Por. Ch. S c h ö n b o r n, Ikona Chrystusa, Poznań 2001, s. 201-202.

54 I,16; por. II,10.13 (PG 94, 1293AD.1297B-1300A).

55. II,14 (PG 94, 1300AD).

56 I,18 (PG 94, 1249A).

57 Por. N. G e n d l e, Creation and Incarnation in the Iconology, s. 644. 
zbawienie” - i zaraz dodaje - „Nie czczę jej jednak tak, jak czczę Boga - broń Boże!"58

Jednocześnie Jan zadaje pytanie: Czyż nie jest materią drzewo krzyża świętego, wzgórze Kalwarii, Grób święty, księga Ewangelii, ołtarz, a także złote krzyże i naczynia liturgiczne, a nade wszystko Ciało i Krew naszego Pana? Jakkolwiek odpowiedź musi być pozytywna, to jednak trzeba przyznać, że w całej tej wizji Jan zbyt słabo podkreśla fakt, że nie każda materia jest w jednakowym stopniu instrumentem zbawienia. Ciało Chrystusa umieszcza na tym samym poziomie, co krzyż, ewangeliarz czy choćby ikonę. Nie dość wyraźnie również zwraca uwagę, że zachodzą między nimi różnice stopnia, jeśli nie wręcz różnice istotowe. Ciało Chrystusa, ze względu na osobową jedność z Logosem, jest bowiem w odmienny sposób „bogopodobne” niż np. ikona, którą z Chrystusem wiąże przede wszystkim to, że obrazowo Go przedstawia. ${ }^{59}$

Tak optymistyczna koncepcja materii i natury wyjaśnia powód, dla którego Jan w tak zaskakująco nikłym stopniu interesuje się samym sposobem plastycznego przedstawienia postaci czy też podobieństwem wizerunku do wzorca. Skoro cała natura od momentu wcielenia przepełniona jest łaską i Bożą energią, to tym bardziej ikona jest takim naczyniem napełnionym łaską. Ukazuje się ona tutaj nie tyle jako obraz, ile przede wszystkim jako coś świętego. Jest tak samo nosicielem Ducha, jak ten, kogo przedstawia. ${ }^{60}$

Wyżej przedstawiona analiza skutków wcielenia, a w konsekwencji całego dzieła zbawczego, dla stanu natury ludzkiej i w ogóle stworzenia pozwala Janowi w nowym świetle przedstawić kwestię obowiązywalności Prawa Mojżeszowego. Kieruje się tutaj myślą św. Pawła, który twierdzi, że przez wcielenie i zmartwychwstanie Jezusa Chrystusa to co dawne przeminęło, a wszystko stało się nowe (por. 2Kor 5, 17). Zatem, „będąc usprawiedliwionymi przez wiarę” (Rz 5,1) „nie jesteśmy już poddani Prawu, lecz łasce” (Rz 6,14), mówi

\footnotetext{
$58 \mathrm{I}, 16$.

59 Por. Ch. S c hö n b o r n, Ikona Chrystusa, s. 204.

${ }^{60}$ Por. tamże.
} 
Paweł. Konsekwencją tej logiki są słowa Jana, które podkreślają konieczność odrzucenia ciężaru Prawa: „I odkąd Syn Boży i Bóg zarazem (...) odkupił naszą winę (...), odtąd staliśmy się naprawdę wolni" ${ }^{11}$ Swoich adwersarzy stawia przed dylematem wyboru - albo Prawo, albo Chrystus: „Jeśli powołując się na prawo, zakazujesz czynienia wizerunków, to tak samo obstawaj o zachowanie szabatu i obrzezania; bowiem te Prawo nakazuje nieustępliwie. Ale wiedzcie, że «jeśli zachowujecie jedynie Prawo, Chrystus wam na nic się nie przyda. Wy, którzy w Prawie szukacie usprawiedliwienia, wypadliście z łaski» (Ga 5, 2.4)"'. ${ }^{62}$

Zdaniem Damasceńczyka, rezygnacja z przedstawień ikonograficznych w wymiarze religijnym, niewątpliwie spowodowałaby zerwanie z chrześcijańskim kerygmatem. ${ }^{63}$ Tworząc obrazy Chrystusa, człowiek ma możliwość upamiętnienia permanentnej i konkretnej zbawczej mocy wcielenia. ${ }^{64}$

\section{Wlaściwy kult obrazów a idolatria}

Do głównych zarzutów wobec legitymizacji praktyki kultu obrazów w Kościele zaliczało się oskarżenie o idolatrię. Oskarżenie to zostaje odparte już przez samo zdefiniowanie przez Damasceńczyka przedmiotu czci - „obrazu" 65 - oraz pojęcia „kult”. Jak bowiem wskazaliśmy, „kult” w rozumieniu Jana Damasceńskiego jest terminem wieloznacznym. Autor określa wiele różnych sposobów oddawania czci, które należą się różnym rodzajom rzeczywistości. Jest zatem

${ }_{61}$ I, 21 (PG 94, 1252B-1256A).

62 I,16; II,14 (PG 94, 1300AD).

${ }^{63}$ Por. K. P a r r y, Depicting the World, s. 70.

64 Por. N. G e n d l e, Creation and Incarnation in the Iconology, s. 644; E. S t a $\mathrm{n}$ i e k, Tajemnica Wcielenia w ujęciu Maksyma Wyznawcy i Jana Damasceńskiego, VoxP 38-39 (2000) 20, s. 336-340.

${ }_{65} \mathrm{Na}$ temat definicji i rodzajów obrazu u Jana Damasceńskiego zob. P. F e 1 i g a, Koncepcja i aksjologia obrazu według Jana Damasceńskiego na podstawie „Trzech mów apologetycznych przeciwko tym, którzy odrzucają święte obrazy”, Studia Theologica Varsaviensia UKSW 47 (2009) nr 1, s. 111-128. 
i taki rodzaj, który przynależy obrazom i stanowi wyraz prawdziwie chrześcijańskiej wiary.

Jak widzieliśmy, jako przykład idolatrii sensu stricto Jan Damasceński wskazuje kult złotego cielca z Wj 32,1nn. Idol, zdaniem Jana, jest obrazem ludzi, zwierząt lub innych stworzeń, które traktuje się jak Boga: „Nie powiedziałem, nie rób obrazu cherubina (...). Powiedziałem, nie czyń sobie żadnych podobizn, nie oddawaj im pokłonów i nie służ jak Bogu, ani nie adoruj stworzenia w miejsce Stworzyciela". ${ }^{66}$ Innymi słowy obraz jest idolem wtedy, gdy wyobrażony przezeń prototyp - stworzenie jest czczony w miejsce Najwyższego Boga - tak, jak czynili to poganie. Ten punkt widzenia przyjął później w swoim orzeczeniu Sobór Ekumeniczny z 787 r. ${ }^{67}$ Nie znaczy to zatem, że idolami są wszystkie obrazy i nie każda cześć oddawana obrazowi jest idolatrią. ${ }^{68}$

Warto zwrócić uwagę, że ikonoklaści nie byli z reguły przeciwni umieszczaniu obrazów w budynkach sakralnych. Ich rola miała się jednak ograniczać tylko i wyłącznie do funkcji dydaktycznej. Funkcję Bibliae pauperum przypisywał obrazom także Grzegorz Wielki i w takiej roli pozostały one w refleksji teologicznej Kościoła zachodniego. Grzegorz pisał mianowicie: „Obraz jest w tym celu wystawiony w kościele, aby ci, którzy nie umieją czytać, przynajmniej patrząc na ściany, czytali na nich to, czego nie mogą czytać w książkach". ${ }^{9}$

Jan Damasceński także posługiwał się tym argumentem na rzecz obrony obrazów: „Czym zatem dla umiejących pisać jest książka, tym dla niepiśmiennych jest obraz". ${ }^{70}$ Jednak ograniczenie się tylko do tego rodzaju argumentów byłoby z jego strony przyznaniem się do klęski. Argument ten nie daje bowiem żadnych podstaw do kultu i liturgicznego wykorzystania świętych wizerunków. Toteż

66 II, 9, por. III, 9 (PG 94, 1332 C).

${ }_{67}$ S o b ó r N i c e j s k i II, Dekret wiary, DSP, t. I, s. 334-338; J. S. M a n s i (wyd.), Sanctorum conciliorum nova et amplissima collectio, XIII, 376C-377E (dalej: Mansi).

68 Por. Th. Si d e r is, The Teological Position, s. 210-211.

${ }^{69}$ Sancti Gregori i Magni, Epistula IX,105, PL 77, 1027D-1028A.

70 I,17 (PG 94, 1248CD). 
Damasceńczyk dokłada najwyższych starań, aby wykazać, że istnieje rzeczywiste odniesienie między obrazem a przedstawioną na nim osobą, które to odniesienie ma stanowić podstawową rację dla kultu obrazów. Ale nawet wyliczenie różnego rodzaju kultu, nie było jeszcze zwieńczeniem dzieła. Aby można było mówić o prawidłowym lub nieprawidłowym kulcie, autor zwraca uwagę na jeszcze jeden element, który w przeciwieństwie do poprzednich ma charakter subiektywny - jest nim intencja.

Dla Jana Damasceńskiego istotna jest zarówno intencja, z jaką tworzy się dany obraz, jak i ta, z jaką osoba modląca oddaje cześć obrazowi. Jeśli obraz jest tworzony ku czci Boga, to jego kult jest ze wszech miar prawidłowy, jeśli zaś ma upamiętniać złego lub bożki, jest godnym potępienia bałwanem. ,Jeśli chodzi o sprawę obrazów, musimy doszukiwać się prawdy i intencji tych, którzy je tworzą. Jeśli rzeczywiście i prawdziwie dla chwały Boga i świętych, dla promowania cnoty, unikania zła i zbawienia dusz, to akceptujemy oddawane im honory. (...) Jeśli ktokolwiek robiłby obrazy, aby czcić diabła i jego demony, żywimy do nich wstręt i wrzucamy do ognia. Albo też jeśli ktoś robi wizerunki człowieka, ptaków, zwierząt czy innych stworzeń - wyklinamy go". ${ }^{71}$

Tymi samymi pobudkami, zdaniem autora, kierowali się bohaterowie Starego Testamentu, kiedy czcili Arkę Przymierza, laskę Aarona lub pojemniki z manną. „Oczywiście przedmioty te nie były same adorowane, ale przez nie (...) uwielbiany był Bóg ich sprawca. Wizerunki te zatem służyły upamiętnianiu rzeczy minionych, czczone zaś były nie jako bóstwa, lecz jako pamiątki Bożego działania". ${ }^{72}$

Bez względu na wagę podziału czci na adorację i zwykły kult relatywny jest on rozróżnieniem czysto pojęciowym. Owo rozróżnienie jakkolwiek samo w sobie jest proste i nie budzące wątpliwości - niemożliwe jest jednak do uchwycenia na drodze praktycznej. Uczeń Jana Damasceńskiego, Teodor Abū Qurrah, na początku IX w. rysuje interesującą paralelę między islamską postawą modlitewną

71 II,10-11 (PG 94, 1293CD).

72 I,17 (PG 94, 1248D). 
a chrześcijańskim kultem obrazów. Teodor pisze: „Każdy, kto dokonuje prostracji przed Bogiem, dotyka kolanami ziemi lub dywanu, ale jest ona kierowana zgodnie z jego intencją do Boga. Tak samo jest z chrześcijanami. Dotykają oni obrazów w akcie prostracji, zgodnie z intencją oddania czci Chrystusowi jako Bogu lub Jego świętym". ${ }^{73}$ Co więcej, taki sposób oddawania czci, prostracja - czyli hołd oddawany przez padanie na ziemię lub przynajmniej głęboki pokłon przed przedmiotem kultu, stał się częścią bizantyńskiej etykiety ceremonialnej już w VI w., odkąd noszone były w procesjach obrazy cesarzy. Świadectwa te pokazują jasno, że sam zewnętrzny akt czci nie może podlegać jednoznacznej ocenie. Aby określić go jako akt idolatrii, prawidłowego kultu czy też zwykłego szacunku, trzeba brać pod uwagę bardziej wewnętrzny element, jakim jest intencja. ${ }^{74}$

Intencja, jako element subiektywny, może podlegać kontroli jedynie w sposób ograniczony. Wyraża się on w zewnętrznym akcie kultu, przez postawę człowieka wobec przedmiotu czci, jest jednak czymś w znacznym stopniu nieuchwytnym. Dlatego też, być może, ów kult budzi tak wielkie kontrowersje. Wymaga on pewnej dojrzałości religijnej. Damasceńczyk jest pełen ufności, nie tyle nawet w stosunku do poszczególnych osób, ile do sensus fidei całego Kościoła. Tę ufność wyrażają nawet, niepozbawione dramatyzmu, słowa z pierwszej mowy: „Uznałem bowiem za (...) więcej niż przerażające, że Kościół lśniący takimi zwycięzcami (...) ulega nędznym żywiołom, drżąc ze strachu wtedy, gdy nie ma się czego obawiać, tak jak gdyby nie poznawszy Boga takim, jakim On jest w swojej istocie, bał się popaść w bałwochwalstwo". ${ }^{75} \mathrm{~W}$ innym zaś miejscu pisze, na czym opiera swoją nadzieję: „Mojżesz, znając synów Izraela, że są twardego serca, i widząc, że łatwo popadają w idolatrię, zabronił im

73 S. H. Griffi is h, Theodore Abū Qurrah's Arabic Tract on the Christian Practice of Venerating Image, Journal of the American Oriental Society 105/1985, s. 68 .

74 Por. K. P a r r y, Depicting the World, s. 166-167.

75 I,2 (PG 94, 1233). 
tworzyć obrazy. Ale my nie jesteśmy tacy sami, bo stoimy pewnie na skale wiary, napełnieni Boską nauką". ${ }^{76}$

Autor zdaje sobie sprawę, że możliwe są różnego rodzaju nadużycia, ale one nie mogą stanowić racji do rezygnacji z kultu obrazów. Potępieni powinni być raczej winni tych nadużyć, którymi są według Jana poganie: „Nie wolno ci też, ze względu na bałwochwalczy kult obrazów u pogan, porzucać naszej pobożnej praktyki", ${ }^{77}$ a dalej zwraca uwagę na to, jak zwodnicze jest podobieństwo zachowań chrześcijan i pogan: „Zaprzysięgają czarownicy i szarlatani, ale i Kościół zaprzysięga katechumenów. Oni przyzywają demonów, ten zaś Boga przeciw demonom. Poganie dedykują obrazy demonom, i nazywają je bogami, my zaś sporządzamy obrazy prawdziwemu i wcielonemu Bogu oraz sługom i przyjaciołom Bożym, i za pomocą tych obrazów przepędzamy całe zastępy demonów". ${ }^{78} \mathrm{~W}$ ten sposób Damasceńczyk nakreślił wyrazistą różnicę w intencji kultu chrześcijańskiego i idolatrii.

\section{Kult obrazów w kontekście kultu świętych}

Jan Damasceński, tak jak i inni ikonofile, doszukiwał się ścisłego związku między wiarą we wstawiennictwo świętych a kultem ich wizerunków. Na taki związek wskazywał chociażby fakt, że już w VII w. funkcjonowała w ikonografii kompozycja zwana Deesis, w której Matka Boska i Jan Chrzciciel wstawiają się ze rodzajem ludzkim do Chrystusa Pantokratora. ${ }^{79}$ Damasceńczyk przeniósł zatem w znacznej mierze punkt ciężkości swojej argumentacji na rzecz czci obrazów na dogmat o świętych obcowaniu.

Między okresem pierwszych męczenników a IV w. kult świętych zdążył się już ustabilizować i przybrał najróżniejsze formy ${ }^{80}$ Grze-

\footnotetext{
76 II,20 (PG 94, 1249).

77 I,24 (PG 94, 1256D-1257A).

78 Tamże.

79 Por. K. P a r r y, Depicting the World, s. 194.

80 Por. tamże, s. 192.
} 
gorz z Nyssy pisze o sposobach postępowania z relikwiami świętych, które sprowadzały się wręcz do fizycznego kontaktu: „Ci, którzy je obejmują, jak gdyby to było żywe ciało w pełni kwitnienia, włączają oczy, usta, uszy, wszystkie zmysły, a wtedy roniąc łzy czci i pasji adresują do męczennika modlitwy o pośrednictwo, jak gdyby byli obecni (w relikwiach)". ${ }^{81}$ Ten cytat cztery wieki później znajduje mocne echo u Jana Damasceńskiego, który mówi na temat obrazów, że, tak jak księgom Ewangelii, również im winni jesteśmy „przyciśnięcie do oczu, warg, serca; pokłon przed nimi, miłość tych, które są podobiznami Boga wcielonego, Jego Matki i społeczności świętych, którzy dzielą cierpienie i chwałę Chrystusa, którzy pokonali i obalili diabła i jego aniołów oraz jego kłamstwo". 82

Inne zgoła było podejście ikonoklastów. Sobór w Hiereia z 754 r. nie podawał co prawda w wątpliwość nauki o obcowaniu świętych, lecz miał wątpliwości co do samego sposobu ich orędownictwa oraz sprzeciwiał się stanowczo kultowi ich relikwii i obrazów. ${ }^{83}$ Cesarz Konstantyn $\mathrm{V}$ zaś był jeszcze radykalniejszy w swoich poglądach; odszedł on nawet od doktryny Soboru w Hiereia. W 760 r. oświadczył bowiem, że orędownictwo Matki Bożej oraz świętych jest nieskuteczne i polecił usunąć relikwie z miejsc kultu. Kult maryjny stał się natomiast przedmiotem jego sarkastycznych żartów. Porównał on mianowicie Theotokos do sakwy, która jest cenna dopóty, dopóki jest pełna, lecz bezwartościowa, gdy jest pusta (tj. po urodzeniu Chrystusa). ${ }^{84}$

Ikonoklaści nie byli jednak na ogół tak radykalni jak cesarz Konstantyn. Zwłaszcza w drugiej fazie konfliktu pojawiały się głosy ikonoklastów, którzy skłonni byli uznać częściowy kult obrazów, np. Chrystusa i Maryi, wykluczając przy tym wizerunki świętych. Takie

81 S. Gregori i Nys s e n i, De S. Theodoro Martyre, PG 46, $740 \mathrm{~B}$.

82 II,10.

83 Por. Mansi, XII, 575-578A.

84 Por. G. D a g r o n, Ikonoklazm i ustanowienie ortodoksji (726-847), w: t e n ż e $\mathrm{i}$ in. (red.), Historia chrześcijaństwa: religia, kultura, polityka, t. IV, Warszawa 1999, s. 100. 
głosy docierały już do Damasceńczyka: „Niektórzy jednak mówią: «Uczyń sobie wizerunek Chrystusa i Jego Matki Bogarodzicy i niech to wystarczy»". ${ }^{85}$ Jan określa takie głosy jednoznacznie jako absurdalne. „Sam siebie czynisz nieprzyjacielem świętych. Jeśli bowiem sporządzasz wizerunki Chrystusa, a żadnych obrazów Jego świętych, to jasne się staje, że nie samego malowania obrazów zakazujesz, ale oddawania czci należnej świętym". ${ }^{86}$

Jan raz jeszcze podkreśla w sposób nie pozostawiający żadnych wątpliwości: „Nie przeciw obrazom prowadzisz walkę, ale przeciw samym świętym". ${ }^{87}$ Ten, kto wzbrania się przed kultem wizerunków świętych, ten w ogóle podważa kult członków Kościoła tryumfującego, a wręcz stawia pod znakiem zapytania autentyczność swojej chrześcijańskiej wiary. „Bez wątpienia człowiek, który przykłada rękę do wyrzucenia obrazu, który został stworzony jako pamiątka chwały Chrystusa, Jego Matki Bogurodzicy lub któregoś z świętych, (...) ani nie oddaje pokłonu i czci należnej obrazom, nie zaś Bogu, ten człowiek jest wrogiem Chrystusa, Bogurodzicy i świętych, zaś obrońcą diabła i jego drużyny" ${ }^{88}$ Podobnie nieprzejednane stanowisko potwierdza później II Sobór Nicejski w 787 r. ${ }^{89}$

Absurdalność stanowiska ikonoklastów ma jeszcze jeden aspekt. Otóż prowadzi ona do powtórnego popadnięcia w niewolę Prawa. To właśnie pod Prawem opłakiwano śmierć sprawiedliwych, a ciała ich uważano za nieczyste; teraz zaś wspomnienia świętych obchodzi się uroczyście i wznosi się nawet świątynie ku ich czci: „Śmierć Jakuba opłakiwano, ale już śmierć Szczepana świętuje się uroczyście. Albo zatem, odwołując się do dawnego Prawa, odrzuć wszystkie uroczyste wspomnienia świętych, albo także przyjmij ich obrazy, które, jak mówisz, sporządzone były wbrew Prawu". ${ }^{90}$

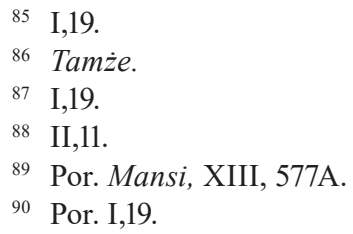


Ikonoklaści byli zwolennikami tzw. etycznej teorii obrazu wyrosłej na gruncie Wj 1,26. Dusza ludzka, jako stworzona na obraz Boży, przywraca Boże podobieństwo przez samodoskonalenie i rozwój cnót. W jej myśl święty jest prawdziwym, ,żywym obrazem” Boga, w przeciwieństwie do „obrazu martwego”, czyli ikony. ${ }^{91}$ Ikonoklaści byli w stanie znaleźć dostateczną liczbę cytatów Ojców na potwierdzenie swojej idei, ${ }^{92}$ ale w ten sposób podkreślali tylko jedną część nauki Ojców na temat imago Dei.

Należy zauważyć jednak, że koncepcja ta była uznawana także przez ikonodulów, z tą różnicą, że jako jedna z wielu doktryn. ${ }^{93}$ Potrafił ją wykorzystać również Jan Damasceński, umiejętnie łącząc ją z wartością edukacyjną obrazów: „Oddaję cześć obrazowi Chrystusa jako wcielonego Boga, obrazowi Pani wszystkich Bogarodzicy jako Matce Syna Bożego oraz obrazom świętych, jako przyjaciół Boga, którzy przelali swą krew w walce przeciw grzechowi a przelewając krew za Chrystusa, naśladowali Go (...) oraz szli Jego śladami. Stawiam sobie przed oczy ich wspaniałe czyny i cierpienia na obrazie przedstawione, aby się przez nie uświęcać i zapałać pragnieniem ich naśladowania". ${ }^{4}$

Autor widzi wreszcie w ikonie element splendoru, jaki święci odbierają po śmierci w królestwie Bożym. Skoro są oni dziedzicami Boga i współdziedzicami Chrystusa (J 15, 14-15), to dlaczego zatem już tu, na ziemi, nie mieliby być współuczestnikami Jego chwały. „Czyż mielibyśmy pozbawiać ich tej chwały, którą obdarzył ich Kościół?"95 W ten sposób uwielbiony jest sam Chrystus, „ponieważ król jest obdarzony czcią, kiedy widzi, że sługa przez

91 Por. K. P a r r y, Depicting the World, s. 193-194; M.V. A n a s t o s, The Ethical Theory of Image Formulated by the Iconoclasts in 754 and 815, Dumbarton Oaks Papers 8/1954, s. 177-188.

92 Por. tami̇e, s. 156-158.

93 Por. K. P a r r y, Depicting the World, s. 194-195.

94 I,21.

95 Tamże. 
niego miłowany jest czczony, nie jako król, lecz jako sługa posłuszny i miłujący przyjaciel". ${ }^{96}$

\section{Obrona obrazów jako element obrony niezależności Kościola}

Świadomość nieomylności, którą daje Kościołowi asystencja Ducha Świętego, determinuje Jana Damasceńskiego do tego, aby z zapałem przeciwstawiać się wszelkim zewnętrznym ingerencjom w życie wspólnoty kościelnej, zwłaszcza ze strony władzy świeckiej.

O ile pierwsza mowa, choć jest najprawdopodobniej reakcją na wydarzenia inspirowane przez imperatora na terenie Bizancjum, nie ma wyraźnie określonego adresata, to druga ewidentnie skierowana jest do cesarza. Treść pierwszego traktatu przybiera miejscami formę polemiki z adwersarzem, któremu autor przypisuje ikonoklastyczne poglądy. Trudno jednak stwierdzić, czy to środek retoryczny, czy też aluzja do poczynań i poglądów urzędującego cesarza - Leona III. Najwyraźniej jednak praca nie przyniosła oczekiwanego skutku, skoro w drugiej mowie zniecierpliwiony Damasceńczyk, wskazując z nazwy urząd cesarza, upomina go zapamiętale. Ostatnia, trzecia mowa $\mathrm{z}$ racji swojej formy systematycznego wykładu nie ma w zasadzie określonego adresata. Mniej w niej zaangażowania, za to obecny jest dystans, na który może sobie pozwolić ktoś, kto nie bierze udziału w samym centrum wydarzeń.

Jan Damasceński wyraźnie rozróżnia w swoim piśmie ustrój kościelny od ustroju państwowego, jak również obydwu porządkom przypisuje zupełnie odmienne kompetencje.

Szukając źródeł organizacji Kościoła, autor sięga do św. Pawła: „Co mówi święty Apostoł? «I tak ustanowił Bóg w Kościele najpierw apostołów, po wtóre proroków, po trzecie nauczycieli, a następnie tych, co mają dar czynienia cudów dla budowania ciała Chrystusa» (por. 1Kor 12,28). Nie wymienia on cesarzy. I znowu: «Bądźcie posłuszni waszym przełożonym i bądźcie im ulegli» (Hbr 13,17). I znowu: «Pamiętajcie o swych przełożonych, którzy głosili wam

96 III,33. 
słowo Boże i rozpamiętując koniec ich życia, naśladujcie ich wiarę» (Hbr 13,7). Cesarze nie głosili wam słowa, tylko apostołowie i prorocy, pasterze i nauczyciele". ${ }^{97}$ Zatem Kościół ma własną hierarchię, ustanowioną przez samego Boga; niezależną od jakiejkolwiek władzy istniejącej na ziemi. Do pieczy jej członków należy „budowanie ciała Chrystusa", a więc sprawowanie władzy w Kościele; im winni są posłuszeństwo wszyscy chrześcijanie; to wreszcie do nich należy głoszenie słowa Bożego - nie do cesarzy. Autor nie ukrywa sarkazmu pod adresem władcy, kiedy pyta: „Manichejczycy napisali Ewangelię według Tomasza; teraz będzie pisana Ewangelia według Leona?"98

Urzędom państwowym Jan Damasceński wyznacza zupełnie inne zadanie - mianowicie troskę o dobro doczesne społeczności. „Polityczne prosperity jest interesem cesarzy". ${ }^{99} \mathrm{~W}$ związku z tym zakres władzy państwowej określa tak, by mógł służyć wytyczonemu celowi: „My będziemy ci posłuszni, imperatorze, w kwestiach związanych z życiem codziennym: opłaty, podatki, daniny; one się tobie należą i będziemy ci je dawać". ${ }^{100}$

Janowa wizja koegzystencji tronu i ołtarza opiera się na zasadzie zaczerpniętej również od świętego apostoła: „«Oddajcie każdemu to, co mu się należy» mówi apostoł Paweł «komu podatek - podatek, komu cło - cło, komu cześć - cześć» (Rz 13,7)”. ${ }^{101}$ Nie ma tu miejsca na konflikty; zadania są jasno wyznaczone, środki również. Możliwa jest zgodna współpraca dla dobra ludu.

Jednak rzeczywistość jest zgoła odmienna. Na opisanie sytuacji, która panuje w Cesarstwie Bizantyńskim, Damasceńczyk używa dosadnych sformułowań. Władcę nazywa tyranem, a jego działania rozbojem. ${ }^{102}$ Stawia go w poczcie władców, którzy źle zapisali się w dziejach Kościoła. „Znam cesarza Walensa, rzekomego chrześ-
97 II,12.
98 II,16.
99 II,12.
${ }^{100}$ Tamże.
101 Tamże.
${ }^{102}$ Por. II,12.16. 
cijanina, który prześladował wiarę ortodoksyjną. Znam Zenona i Anastazego, Herakliusza i Konstantyna z Sycylii, który zwany był Bardanes Filipikus". ${ }^{103}$ Pierwszy z nich - Walens (364-378), jako wyznawca arianizmu wsławił się prześladowaniem zwolenników Soboru Nicejskiego z 325 r., m.in. za obronę ortodoksji wygnał ze swojego biskupstwa w Aleksandrii św. Atanazego. ${ }^{104}$ Zenon Izauryjczyk (474-491) starał się nakłonić chalcedończyków do kompromisu z monofizytami, wydając dekret Henotikon, dążył zatem do politycznej jedności obydwu stronnictw kościelnych kosztem prawdziwej wiary. Anastazy (491-518), jego następca, kontynuował politykę swojego poprzednika. ${ }^{105}$ Herakliusz (610-641) sprzyjał monoenergizmowi, a następnie monoteletom, których doktrynę starał się narzucić całemu Kościołowi dekretem znanym jako Ekthesis. ${ }^{106}$ Autor wykazuje w ten sposób, że świeckie metody rządzenia nie znajdują zastosowania w Kościele. Nie da się w nim niczego zadekretować, co by było sprzeczne z Ojcami i Tradycją. „Nie uwierzę, że porządek w Kościele opiera się na edykcie cesarza, ale na tradycjach Ojców, pisanych i niepisanych". ${ }^{107}$

Przyczyn konfliktu ikonoklastycznego w Cesarstwie Jan Damasceński upatrywał w pomieszaniu materii działalności władzy kościelnej i świeckiej. Władza państwowa po raz kolejny wkraczała w zakres spraw duchowych. To musiało spotkać się ze stanowczym sprzeciwem tych, którym leżała na sercu wolność Kościoła. Twórczość Damasceńczyka była przejawem takiego właśnie non possumus, które pojawiało się zawsze wtedy, gdy zagrożona była prawdziwa wiara. „Nie pozwolę, żeby tyrański imperator wkraczał w sprawę kapłańską - pisał. - Imperator nie otrzymał przecież władzy związywania i rozwiązywania". 108

${ }^{103}$ II,16.

${ }_{104}$ Por. L. J. R o g i e r i in. (red.), Historia Kościoła, t. I, Warszawa 1986, s. 206-207.

105 Por. tamże, t. I, s. 267.

${ }^{106}$ Por. tamże, t. II, s. 69

107 II, 16 (PG 94, 1301).

108 II,16; 
Damasceńczyk miał mnóstwo poprzedników w walce z władzą państwową i to niemal w każdym pokoleniu wyznawców Chrystusa. Zawsze wtedy, gdy imperatorzy ingerowali w sprawy kościelne. Schönborn zwraca jednak uwagę, że Damasceńczyk nie tylko przeciwstawia się decyzjom imperatora, ale także nadał tym działaniom teoretyczne podstawy. , Jan zasłużył się tym również, że z wyjątkową jasnością określił granice władzy cesarza w sprawach wiary" ${ }^{109}$

Tak zdecydowana postawa antycesarska Jana mogła być powodem, dla którego nie był on cytowany przez Sobór Nicejski w 787 r., tak samo z resztą jak Jerzy z Cypru, znany również ze swoich bezkompromisowych antyreżimowych wypowiedzi. Na nich obu, oraz na patriarchę Germana, Sobór ikonoklastyczny w 754 r. nałożył anatemę i wszyscy trzej zostali zrehabilitowani w Nicei. A mimo to cytowane są tylko fragmenty pism Germana. ${ }^{110}$ Bywało to interpretowane jako nieznajomość pism Damasceńczyka przez Ojców Soboru. Trzeba jednak zdawać sobie sprawę z faktu, że zgromadzeni w Nicei biskupi reprezentowali w zdecydowanej większości Kościół podlegający władzy cesarza. Nie zależało im zatem na podkreślaniu roli władców bizantyńskich $\mathrm{w}$ inicjowaniu ikonoklazmu lub organizowaniu prześladowań - nawet jeżeli już nie żyli. Jan Damasceński, pisząc w cieniu władzy Omajjadów, mógł posunąć się o wiele dalej w swoich opiniach na ich temat. ${ }^{111}$

\section{Tradycja a kult obrazów}

„Uznając przede wszystkim tradycję Kościoła, przez którą przyszło zbawienie, za podstawę i fundament dla mojego rozważania, zniosłem wszelkie bariery dla słowa i wypuściłem je, jak gotowego do biegu konia"112 - pisze Jan Damasceński. Za pomocą tak wzniosłego i poetyckiego stylu wypowiedzi autor podkreśla niebagatelną

\footnotetext{
${ }^{109}$ Ch. S c hö n b o r n, Ikona Chrystusa, s. 206.

110 Por. K. P a r r y, Depicting the World, s. 136.

111 Por. tamże, s. 137.

${ }^{112} \mathrm{I}, 2$
} 
rolę Tradycji, jaką przypisuje w argumentacji na rzecz obrony kultu świętych wizerunków.

Lektura wszystkich trzech mów sugeruje wręcz, że autor traktuje kwestię obrazów nie tyle jako kwestię zasadniczą, ale jako pochodną innego, znacznie istotniejszego problemu, jakim jest nienaruszalność Tradycji Kościoła. Wydaje się, że właśnie obrona Tradycji była bodźcem do powstania powyższych apologii. Takie podejście wydaje się iść w parze ze sformułowanym przez K. Parry’ego ogólnym stwierdzeniem, że cały spór dotyczący obrazów można, bez zbytniego uproszczenia, sprowadzić do kwestii centralnego miejsca Tradycji w Kościele bizantyńskim. ${ }^{113}$ Tezę tę potwierdza gorący apel, z jakim Jan zwraca się w podsumowaniu florilegiów kończących dwie pierwsze mowy: „Dlatego też zaklinam Lud Boży, Naród Święty, ażeby mocno trwał związany tradycjami kościelnymi, albowiem eliminowanie (...) czegokolwiek, z tego, co zostało nam przekazane, podobnie jak kamienie wyjęte z budynku, sprawia, że wkrótce upada cały dom". ${ }^{14}$

Problem, którym teraz się zajmujemy, zostanie rozbity na dwa odrębne zagadnienia: stosunek Jan Damasceńskiego do tradycji niepisanej oraz do autorytetu Ojców Kościoła.

\section{Stosunek do tradycji niepisanej}

Damasceńczyk kładzie ogromny nacisk na ochronę całości depozytu wiary. Powodem takiego stanowiska jest głębokie przeświadczenie, że Tradycja w tym samym stopniu co Pismo stanowi jedno, integralne źródło objawienia.

Tak zwany Kodeks Muratoriego dowodzi, że większość pism Nowego Testamentu już w końcu II w. funkcjonowała w postaci ustalonego kanonu. Jednakże chronologia daje pierwszeństwo właśnie tradycji ustnej. Jeszcze św. Ireneusz z Lyonu dopuszcza myśl, że apostołowie mogliby w ogóle nie pozostawić po sobie żadnych

113 Por. K. P a r r y, Depicting the World, s. 156.

114 I,68 (PG 94, 1284A). 
Pism, a i tak Kościół nic by nie stracił pilnie przestrzegając „zdrowej i dawnej tradycji". ${ }^{15}$ Ale nawet w momencie, kiedy spisywane były ustne tradycje dotyczące Jezusa, nie zaprzestawano dalszego przekazywania tradycji niepisanych. Przeciwnie, funkcjonowały one dalej obok pism Nowego Testamentu i wywierały wpływ na myślenie chrześcijańskie. Pismo zaś nie stało się nigdy jedynym źródłem objawienia i miało być interpretowane w zgodzie z tradycjami - zachodziła zatem między nimi bardzo ścisła zależność. ${ }^{116}$

Tak więc autorytet Tradycji uznawany był w Kościele od samego początku. Pierwotnie jej przedmiotem były przede wszystkim nie spisane wypowiedzi Jezusa, tzw. agrapha, o czym daje świadectwo Papiasz,${ }^{117}$ oraz symbole wiary - jak u Arystydesa. ${ }^{118}$ Później, w miarę oddalania się od czasów apostolskich, w jej obręb wchodziły głównie zwyczaje liturgiczne. Orygenes pisał: „Słyszymy słowa Pisane naszego Ojca, ale także nie pisane tradycje naszej matki, Kościoła, jak na przykład post w piątek i inne zwyczaje". ${ }^{119}$ Wydaje się jednak, że odwołania do tradycji niepisanych nie były w zasadzie brane pod uwagę przez Ojców II i III w. jako argumenty w rozstrzyganiu kwestii doktrynalnych. Liczne odniesienia pojawiły się natomiast dopiero u teologów IV w. ${ }^{120}$

Do sytuacji, w której zwolennicy ikon odnoszą się do kultu ikony, jako części tradycji niepisanej, w znacznym stopniu przyczynił się

115 S. Irenaei Episcopi Lugdunensis et Martyris, Adversus haereses 3, 4,1-2, PG 7, 855B-856A.

116 Por. K. P a r r y, Depicting the World, s. 156.

117 Por. E u s e bi i Ca e s a r i e n s is, Historia Ecclesiastica 3, 39, 3-4 PG 20, 296B-297A; E u z e bi u s z z C e z a re i, Historia Kościelna. O męczennikach palestyńskich, tłum. A. L i s i e c k i, w: J. S a j d a k (red.), Pisma Ojców Kościoła w polskiem tlumaczeniu, t. III, Poznań 1924, s. 141.

118 Por. A r is t i d e s, Notitia, PG 5, 1267-1268; S. P i e s z c z o c h, Patrologia, Poznań 1964, s. 68.

119 O r y g e n e s, Origenis fragmenta in proverbia, PG 17, 157A.

${ }^{120}$ Por. K. P a r r y, Depicting the World, s. 157; R.P.C. H a n s o n, Tradition in the Early Church, Londyn 1962, s. 244. 
św. Bazyli. ${ }^{121}$ Powoływał się on na przekazy ustne, gdy bronił tradycyjnej doksologii „z Duchem Świętym”, uzasadniał praktykę adorowania krzyża oraz używania epiklezy podczas konsekracji. Bazyli pisze bowiem, że część nauki została przejęta z niepisanej tradycji apostolskiej przekazanej „,W tajemnicy”. ${ }^{122}$ Przy czym termin „w tajemnicy" (en mysterio) może być tu rozumiany w dwojaki sposób: albo, idąc za myślą Papiasza, jako ezoteryczna wiedza, przekazana przez apostołów tylko nielicznym, albo też, co bardziej prawdopodobne, jako wiedza przekazywana ,przez ustne wtajemniczenie” podczas katechezy. ${ }^{123}$

Jan Damasceński przytacza te kluczowe słowa Bazylego w swojej pierwszej mowie: „Tradycja Kościoła została nam przekazana nie tylko za pośrednictwem pisma, ale przekazywano ją także w formie niepisanej. Mówi o tym św. Bazyli (...): «W całym starannie strzeżonym przez Kościół nauczaniu i doktrynie, część nauki posiadamy w formie pisanej, część zaś tradycji apostolskiej została nam tajemniczo (en mysterio) przekazana w formie niepisanej, oba zaś te źródła mają jednakową moc, aby prowadzić nas do zbawienia»". ${ }^{124}$ Kontynuując ten tok myślenia, Jan Damasceński właśnie niepisanej tradycji Kościoła jerozolimskiego przypisuje znajomość lokalizacji takich obiektów jak Góra Kalwaria czy Grób Pański: „Czyż dzieci nie dowiedziały się o tym ustnie od ojców?"'125 Również w ślad za Bazylim Damasceńczyk pyta o pochodzenie pewnych rytów litur-

${ }^{121}$ W tym kontekście odnosi się do Bazylego-poza Janem Damasceńskim - również patriarcha N i c e fo r; zob. t e n ż e, Antirrheticus III, 8, PG 100, 389AB.

${ }_{122}$ Por. S. B a s 11 i i Ma g n i, De Spiritu Santo 27, 66, PG 32, 188AB; Św. B a zyli Wielki, O Duchu Świętym, s. 175; E. A mand de Mendiet a, The „Unwriten” and „Secret” Apostolic Traditions in the Theological Thought of St. Basil of Caesarea, Edynburg 1965.

${ }^{123}$ Traktowanie niepisanej tradycji apostolskiej jako wiedzy ezoterycznej pozbawiałoby ją wiarygodności. Z twierdzeniami Papiasza nie zgadzał się już Euzebiusz z Cezarei w Hist. Eccl. 3, 11-12 (PG 20,240C-248A); E u z e b i u z z z C e z a re i, Historia Kościelna, s. 109-111.

${ }^{124}$ I, 23 oraz S. B a s 11 i i, De Spir. 27, 66, PG 32, 188AB; Św. B a z y 1 i W i e 1 k i, O Duchu Świętym, s. 175.

${ }^{125} \mathrm{I}, 23$. 
gicznych; skąd mianowicie wziął się zwyczaj potrójnego zanurzania w wodzie podczas chrztu świętego, modlenia się zwróconymi w kierunku wschodnim czy też sposób sprawowania liturgii. Nie ma wątpliwości, że pochodzą one ze źródeł niepisanych. ${ }^{126}$

W ten sposób Jan Damasceński dochodzi do niezachwianego przekonania, że także kult świętych obrazów jest praktyką równie starożytną, co pozostałe zwyczaje liturgiczne i sięga czasów apostolskich. Pisze mianowicie: „Przyjmij za pojedynczy strumień dziedzictwo Pisma i Ojców; ono pokazuje, że tworzenie i czczenie obrazów nie jest nowinką, ale starożytną Tradycją Kościoła". ${ }^{127}$ Przystanie na błąd ikonoklazmu oznaczałoby jego zdaniem naruszenie integralności Bożego objawienia. Taka teza kryje się za retorycznym pytaniem, które kieruje do swojego adwersarza: „Skoro więc tak wiele zostało przekazane Kościołowi w formie ustnej i jest aż po dziś dzień pieczołowicie strzeżone i zachowane, pytam, dlaczego z pogardą odnosisz się do świętych obrazów?"128

Ikonoklaści z dużym sceptycyzmem oceniają wartość tradycji ustnej, jako wiarygodnego źródła przekazu wiary. Ich nacisk na słowo pisane nie pozwala im wywieść kultu ikon ani z tradycji pochodzącej bezpośrednio od Chrystusa, ani od apostołów, ani od Ojców Kościoła; uważają tę praktykę za zerwanie z prawdziwą Tradycją, i narażanie Kościoła na wpływ pogaństwa. Są przekonani, że Tradycja właśnie im przyznaje rację, natomiast brak pisemnych przekazów popierających kult ikon z okresu wczesnego Kościoła uważają za mocny dowód na rzecz swojego stanowiska. Dla ikonofilów zaś przeciwnie, dowodem bardziej wartościowym było dotarcie do pokładów tradycji niepisanej. ${ }^{129}$

W charakterystycznej dla ikonoklastów skłonności do „cenzurowania” Tradycji Damasceńczyk dopatruje się tendencji reformistycznych. Dopuszczenie do rozpoczęcia tego procesu mogłoby przynieść nieobliczalne skutki, a w konsekwencji doprowadzić

\footnotetext{
126 Por. tamże.

127 II,20.

${ }^{128}$ I,23; por. II,16 (PG 94, 1301C-1304A).

${ }^{129}$ Por. K. P a r r y, Depicting the World, s. 160.
} 
nawet do upadku całego gmachu Kościoła świętego. Kontynuując cytat ze św. Bazylego, Jan ostrzega: ,Jeśli bowiem próbujemy odrzucać niepisane zwyczaje, jako nie mające wielkiego znaczenia, możemy czyniąc to wyrządzić krzywdę tym, które w Ewangelii mają istotne znaczenie". ${ }^{130}$ Autor apeluje zatem w dramatycznych słowach: „Stójmy bracia mocno na skale wiary i tradycji Kościoła, bez przesuwania granic, które ustalili nasi Ojcowie (por. $\mathrm{Rz} 22,28)$, nie dając miejsca tym, którzy chcą wprowadzić nowości i zburzyć budynek świętego Kościoła Bożego, katolickiego, i apostolskiego". ${ }^{131}$

Skoro Damasceńczyk traktuje jako jednolite testimonium - Pismo i Ojców, uważa Tradycję za, w pewnym sensie, kontynuację Bożego objawienia, gdzie natchnieni przez Ducha Ojcowie dokonują prawdziwej wykładni Pisma Świętego. ${ }^{132}$ Dzięki owej asystencji Ducha Kościół nie musi się więc obawiać „ulegnięcia nędznym żywiołom”, ${ }^{133}$ które mogłyby go zwieść na manowce. Ta charakterystyczna dla Jana Damasceńskiego optymistyczna postawa wobec wartości poznawczej tradycji niepisanej została uznana przez II Sobór Nicejski i usankcjonowana $\mathrm{w}$ jego czwartym anatematyzmie potępiającym tych, którzy odrzucają jakąkolwiek tradycję kościelną, czy to pisaną, czy niepisaną. ${ }^{134}$

${ }^{130}$ I,23 oraz S. B a s 11 i i, De Spir. 27, 66, PG 32, 188AB; Św. B a z y l i, O Duchu Świętym, s. 175.

131 III,41.

${ }^{132}$ Por. K. P a r r y, Depicting the World, s. 162. W podobnym duchu pisał już Grzegorz z Nazjanzu, który twierdził, że bóstwo Ducha Świętego zostało wyjaśnione nie w Piśmie, ale później, przez jednego z teologów (prawdopodobnie miał na myśli Grzegorza Cudotwórcę - PG 10, 984), który nauczał tego, jak twierdzi Nazjanzeńczyk, pod natchnieniem Ducha Świętego; por. Oratio 31, 26-28, PG 36, $161 \mathrm{C}-165 \mathrm{~A}$; Św. Grzegor z z N a zja n z u, Mowy wybrane, s. 358-360.

133 Por. I,2

134 Por. S o bó r N i c e j s k i II, Anatematyzm 4, DSP, t. I, s. 341; BF III, 7. 
Stosunek do pism Ojców

Na końcu każdej z trzech mów Jan Damasceński umieszcza kolekcje tekstów, które składają się z fragmentów prac autorów kościelnych.

Metoda cytowania Ojców Kościoła w celu poparcia swoich twierdzeń teologicznych stosowana była od wieków. Stanowi ona niejako przedłużeniem metody, polegającej na posługiwaniu się „dowodami” z Pisma Świętego. Maksym Wyznawca twierdził, że Ojcowie są spadkobiercami apostołów i mają równy im autorytet. ${ }^{135} \mathrm{~W}$ stuleciach VIII i IX stosowanie antologii cytatów patrystycznych uważano już za praktykę konieczną, aby jakakolwiek doktryna teologiczna mogła być uznawana za obowiązującą. Takie florilegia skompilowano zatem dla obydwu zgromadzeń ikonoklastycznych: w Hiereia w 754 i w Hagia Sophia w 815 r., w celu zatwierdzenia przez zebranych tam biskupów. ${ }^{136}$ Analogiczną antologię stworzyli ikonofile na Siódmym Soborze Ekumenicznym w 787 r. ${ }^{137}$

$\mathrm{Na}$ upowszechnienie się tej metody miała w tym czasie wpływ centralna idea wierności Ojcom i tradycjom Kościoła. Nie oznaczało to bynajmniej, że teologia bizantyńska nie miała reagować na nowe wyzwania. Powinna natomiast być tworzona w relacji do tego, co powstało już wcześniej, jako twórcza refleksja nad materiałem pozostawionym przez wcześniejsze autorytety. Wspomniany wyżej Maksym Wyznawca przyznaje, za św. Bazylim Wielkim, że nic z tego, co sam napisał, nie zostało wymyślone przez niego, ale pochodzi od Ojców. ${ }^{138}$ Również Jan Damasceński jest dobrym przykładem takiej postawy. W jednej z mów pisze on nawet: „Jeśli ktokolwiek chciałby głosić ci coś przeciwnego do tego, co Kościół katolicki otrzymał od świętych Apostołów, Ojców i soborów, a ustrzegł do dnia dzisiejszego,

${ }^{135}$ Por. J. P e l i k a n, The Spirit of Eastern Christendom (600-1700), Chicago 1974, s.19-21.

136 Por. P.J. A 1 e x a n d e r, The Patriarch Nicephorus of Constantinople: ecclesiastical Policy and image worship in the Byzantine empire, Oxford 1958, s. 493-505.

${ }^{137}$ Mansi, XIII, 1-201; por. K. P a r r y, Depicting the World, s. 145-146.

${ }_{138}$ Por. Mak s y m W y z n a w c a, The Philokalia. The complet text, t. II, s. 286; por. też S. B a s 11 i i, De Spir., PG 32, 72-73. 
nie słuchaj go". ${ }^{139}$ Jego De fide orthodoxa natomiast, które stanowi próbę całościowego ujęcia dogmatyki chrześcijańskiej, nie zawiera w zasadzie oryginalnej myśli autora, za to prezentuje wysoki poziom systematyzacji tradycji patrystycznej. ${ }^{140}$

Taką postawę Damasceńczyka trzeba widzieć również w kontekście 19 kanonu Soboru Piąto-Szóstego z 692 r., który brzmi: „Przełożeni kościoła powinni (...) nauczać (...) nie przestępując już utrwalonych przez bogonośnych Ojców granic (...). I jeśli słowo Pisma będzie badane, to niech objaśniają go nie inaczej, jak przedstawili go w swoich pismach luminarze i nauczyciele Kościoła, i tym niech się zaspokoją bardziej, niż układaniem własnych słów, aby, z braku umiejętności, nie uchylić się od tego, co należy". ${ }^{141} \mathrm{Na}$ decyzję Soboru wpłynęły bez wątpienia polityczne i eklezjalne wstrząsy VI i VII w. Po tych doświadczeniach Kościół dążył do ujednolicenia języka, w którym formułowana jest doktryna, by utrudnić możliwość wszelkiego ,nowinkarstwa”. ${ }^{142}$

Janowe florilegia zawarte w dwu pierwszych mowach przeciwko obrazoburcom są sobie najbliższe, zwłaszcza pod względem treści. Kolekcja z drugiej mowy jest de facto powtórzeniem pierwszej, tyle że uzupełniona o kilka nowych wyjątków. Forma obydwu antologii wskazuje na to, że autor traktuje je jako integralne części traktatów. Cytaty wyposażone są w dłuższe lub krótsze komentarze, które korespondują z argumentacją samych mów, całość natomiast finalizują rozbudowane zakończenia. Trzecie zaś florilegium, które jest o kilkanaście lat późniejsze od dwu pozostałych, stanowi jakby osobną całość, która sama w sobie może dobrze służyć apologii obrazów. Jest to niemal całkowicie nowy wybór tekstów, z mowami wcześniejszymi pokrywa się w niewielkim stopniu. Zawiera znacznie większą liczbę autorów, a tylko kilka komentarzy własnych Damasceńczyka.

139 II,6.

${ }^{140}$ Por. K. P a r r y, Depicting the World, s. 147.

${ }_{141}$ A. Z n o s k o, Kanony Kościoła prawosławnego w przekładzie polskim, t. I, Warszawa 1978, s. 82.

${ }^{142}$ K. P a r r y, Depicting the World, s. 148. 
Ustalenie dokładnej liczby cytatów i ich autorów napotyka pewne trudności. Po pierwsze, zdarza się, że w relacjonowaniu tekstów patrystycznych autor posługuje się mową zależną lub też, cytując Ojców, dokonuje pewnych skrótów i modyfikacji tekstu. Po wtóre, prezentuje jako tekst ciągły zdania, które są w rzeczywistości rozrzucone na większej przestrzeni dzieła źródłowego. ${ }^{143}$ Nasuwa to wątpliwości, czy można dany tekst traktować jako pojedynczy cytat. Następnie, zdarza się, że Jan błędnie przypisuje autorstwo ${ }^{144}$ lub podaje teksty, których nie sposób zidentyfikować, gdyż nie ma ich wśród dostępnej dziś literatury patrystycznej. ${ }^{145}$ To w oczywisty sposób utrudnia ustalenie prawdziwej liczby cytowanych autorów.

Jeśliby wykazać, że Jan Damasceński posługiwał się w tworzeniu swoich kolekcji jakimiś wcześniejszymi zbiorami cytatów, można by wtedy po części wyjaśnić zaistniałe błędy automatycznym powielaniem zwartych w nich pomyłek. K. Parry twierdzi jednak, że Jan posługiwał się na ogół oryginalnymi źródłami, ${ }^{146}$ natomiast B. Kotter znalazł we florilegium do trzeciej mowy jedenaście lemmata, pochodzących z Doctrina patrum de incarnatione Verbi, ważnej antologii chrystologicznej z VII w. ${ }^{147}$ Kwestia dostępności źródeł wymaga osobnych studiów. Należałoby mianowicie porównać cytowane przez naszego autora fragmenty z urywkami zachowanymi w różnych kolekcjach florilegiów.

${ }^{143}$ Np. I,56 (PG 94, 1272B-1276A); II,52 (PG, 94, 1313A), por. L e o n t i i N e a p ol it a n i E p i s c o p i, Sermo contra Judaeos, PG 93, 1601A, 9-15; 164A, 3-11; 1608D, 5-7; 1605B, 11-C4; 1505B, 1-11; 1605D, 9-1608A, 10; 1608B,7-12; 1608C, 11-D1; $1608,11-\mathrm{C} 11$.

${ }^{144}$ Np. I,64 (PG 94, 1280A). Według Kottera, nie jest to fragment z pisma Sofroniusza z Jerozolimy Leimonárion, jak twierdzi Jan Damasceński, ale jego przyjaciela Jana Moschosa: PG 87, 2900B.

${ }^{145}$ B. Kotter znalazł pięć takich fragmentów.

146 Por. K. P a r r y, Depicting the World, s. 148.

147 Por. B. K o t t e r (wyd.), Schriften des Johannes von Damasko, t. III, Berlin 1975, s. 31; F. D i e k a m p (wyd.), Doctrina Patrum de incarnatione Verbi, Münster 1907. 
Należy stwierdzić, że, powołując się na Ojców Kościoła, twórcy kolekcji kierowali się na ogół dwoma ważnymi zasadami: antyczności (im źródło wcześniejsze tym lepiej) i ortodoksji. Po raz pierwszy termin „Ojcowie” użyty został przez Atanazego i Bazylego Wielkiego w odniesieniu do biskupów uczestniczących w Soborze Nicejskim w 325 r. ${ }^{148}$ Poza tym, Bazyli używał go jeszcze, odnosząc się do pisarzy przednicejskich, w tym do Ireneusza Antiocheńskiego, Klemensa Rzymskiego i Orygenesa.

Bazyli jest jednym z pierwszych autorów, którzy tworzyli listy autorytetów patrystycznych dla poparcia swoich argumentów teologicznych. Jednakże do końca $\mathrm{V}$ w. w patrystycznych florilegiach pojawiało się bardzo niewielu pisarzy przednicejskich. W efekcie kontrowersji nestoriańskiej pojęcie „Ojcowie” zostało w tym czasie ograniczone do tych autorów, którzy opowiedzieli się po stronie nicejskiego credo. ${ }^{149}$

Pod wpływem Cyryla Aleksandryjskiego zaczęła się kształtować idea kanonu wybranych autorów. W wyniku tego procesu autorytet jednych Ojców został wyniesiony ponad autorytet innych. ${ }^{150}$ Drugi Sobór Konstantynopolitański z 553 r. wypowiedział się na korzyść pism 12 Ojców, w tym Atanazego, Bazylego i właśnie Cyryla Aleksandryjskiego. ${ }^{151}$ Zatem pole manewru zostało dość mocno zawężone.

Podczas kontrowersji obrazoburczej strona ikonoklastyczna trzymała się ściśle tych wyśrubowanych kryteriów. Bardzo poważnie traktowali oni zasadę starożytności autorów i ograniczali się w swoich florilegiach do cytowania jedynie tekstów z IV i V w. ${ }^{152}$ Jest

148 Por. R.M. G r a n t, The Appeal to the Early Fathers, Journal of Theological Studies 11/1960, s. 16.

149 Por. K. P a r r y, Depicting the World, s. 145.

${ }^{150}$ Por. P.T.R. Gr a y, „The Selects Fathers”: Canonizing the Patristic Past, Studia Patristica 23/1989, s. 24; R.M. G r a n t, The Appeal to the Early Fathers, s. 14.

${ }^{151}$ Por. H. R. P e r c ival (wyd.), The Seven Ecumenical Councils of the Undivided Church, t. IV, Oxford 1981, s. 303.

${ }_{152}$ Por. M.V. A n a s to s, The Argument for Iconoclasm as presented by the Iconoclastic Council of 754, w: K. W e i t z m a n n (wyd.), Late Classical and Medieval Studien in Honor of A.M. Friend, Princeton 1955, s. 182-184. 
to postawa bardzo dla nich wygodna, gdyż nie wiele było źródeł na temat kultu obrazów przed VI w. ${ }^{153}$ Stanowiło to natomiast problem dla ikonofilów. Nic zatem dziwnego, że zdecydowali się oni włączyć do patrystycznych testimoniów autorów późniejszych. Trzeba jednak zdawać sobie sprawę z tego, że w VI i VII w. dysputy teologiczne przyczyniły się znacznie do poszerzenia zawartości patrystycznych florilegiów. Można w nich znaleźć odwołania do pism wziętych z późniejszych i mniej znaczących autorów. Na przykład Doctrina patrum zawiera już teksty ok. dziewięćdziesięciu Ojców Kościoła. ${ }^{154}$

Jak się okazuje, starożytność nie była dla ikonodulów barierą do uznania autorytetu danego pisarza. Ten brak odnośników do kultu - choć już nie samego tworzenia - obrazów ze „złotego” okresu patrystyki może być tłumaczony dwojako, albo uważano go za oczywistość, i tylko kontrowersje wokół tematu wywołały w późniejszym okresie konieczność ustosunkowania się do tej kwestii, albo też w przeciwieństwie do tego, co mówili ikonofile - był to rzeczywiście zupełnie nowy fenomen. ${ }^{155}$

Powyższe uwagi na temat kształtowania się patrystycznego kanonu i stosunku do niego stron sporu ikonoklastycznego rzucają pewne światło na skład florilegiów ułożonych przez Jana Damasceńskiego. W pierwszym z nich na ok. dziesięciu autorów ponad połowa to pisarze z VI i VII w., w drugiej antologii Damasceńczyk dodaje jeszcze przynajmniej dwóch późnych autorów, chociaż należy zwrócić uwagę, że w obydwu najsilniej reprezentowany jest jednak św. Bazyli. ${ }^{156}$

Wśród Ojców, którzy pojawiają się dopiero w trzecim florilegium, należy wymienić dwóch pisarzy przednicejskich - Klemensa Aleksandryjskiego ${ }^{157}$ i Metodego z Olimpu, ${ }^{158}$ natomiast prawie wszy-

${ }^{153}$ Por. K. K it z i n g e r, The Cult of Images in the Age before Iconoclasm, Dumbarton Oaks Papers 9/1954, s. 94.

${ }_{154}$ Por. K. P a r r y, Depicting the World, s. 147-148, 152.

155 Tamże, s. 152.

156 I, 34-47 (PG 94, 1261C-1268D).

157 III,112 (PG 94, 1404AB).

${ }^{158}$ III,138 (PG 94,1420A). 
scy pozostali to Ojcowie z IV i V w. Świadczy to o tym, że kwestia starożytności było dla Jana jednak ważnym kryterium, ale potrzebował więcej czasu na skompletowanie odpowiedniego materiału.

Mimo trudności, o których mówiliśmy wcześniej, K. Parry pokusił się o zestawienie świadectw głównych Ojców cytowanych we florilegiach Jana Damasceńskiego. Oto oni: Ambroży z Mediolanu (2), ${ }^{159}$ Anastazy z Antiochii (3), Anastazy Apokryzariusz (2), Anastazy z Synaju (1), Atanazy Aleksandryjski (3), ${ }^{160}$ Bazyli Wielki (7), Jan Chryzostom (4), Klemens Aleksandryjski (1), Cyryl Aleksandryjski (3), Cyryl Jerozolimski (1), Pseudo-Dionizy (4), Euzebiusz z Cezarei (2), Grzegorzy z Nazjanzu (4), Grzegorz z Nyssy (3), Leoncjusz z Neapolis (8), Sewerian z Gabala (3), Sofroniusz z Jerozolimy (2), Stefan z Bosry (2), Symeon Stylita Młodszy (1). Poza tym Parry na podstawie Kottera odnajduje 12 fragmentów z Doctrina patrum. ${ }^{161}$ Pomija natomiast pomniejszych autorów, jak np. Jan Malalas, Teodor Lektor czy Izydor Diakon.

Pierwsza uwaga, która narzuca się po zapoznaniu z listą świętych autorów, jest taka, że mieści się ona całkowicie w obrębie pisarzy języka greckiego - nie ma tam ani jednego autora zachodniego. Jan Damasceński nie odwołuje się nawet do wypowiedzi papieża Grzegorza Wielkiego, który był przychylny obrazom i podkreślał ich rolę edukacyjną. ${ }^{162}$ Świadczy to o skromności związków, jakie łączyły już wtedy obie części Kościoła, a zarazem o sile teologii greckojęzycznej, która w sytuacjach kryzysowych, takich jak kontrowersja ikonoklastyczna, była w stanie poradzić sobie sama z wyzwaniami epoki.

Lektura florilegiów pokazuje, że znaczna część argumentów, którymi posługuje się Damasceńczyk, została ukuta już podczas wcześniejszych sporów i dyskusji teologicznych. Problem idolatrycznego

159 Liczba w nawiasie oznacza liczbę cytatów danego autora.

${ }^{160}$ Różnice w liczbie cytatów wynikają z faktu, że Parry uwzględnia również cytaty zawarte poza florilegiami - wewnątrz mów.

${ }^{161}$ K. P a r r y, Depicting the World, s. 153.

162 Sancti Gregori i Magni, Epistola IX,105, PL 77, 1027B-1028A; Epistola XI,13, PL 77, 1128A-1130B. 
kultu przedmiotów materialnych, zwłaszcza postaci krzyża, ale także obrazów oraz jego stosunek do Prawa był nieodłącznym elementem polemik z wyznawcami judaizmu. Są one obficie reprezentowane przez fragmenty pism Leoncjusza z Neapolis i Stefana z Bosry obydwu pod znamiennym tytułem Przeciwko Żydom. ${ }^{163}$ Natomiast kolekcja Doctrina patrum, którą prawdopodobnie wspierał się Jan, tworzona była w polemice $\mathrm{z}$ herezją monofizytyzmu.

Innym, bardzo ważnym fragmentem, wymienionym wśród pism Ojców jest przytaczany już przez nas wcześniej cytat ze św. Bazylego, w którym stwierdza on, że cześć oddawana obrazom, odnosi się do prototypu. ${ }^{164}$ Był on później wielokrotnie wykorzystywany jako mocny argument przez późniejszych obrońców obrazów. ${ }^{165}$ Jednakże kontekst, w jakim znalazł się obecnie, był dla niego zupełnie nowy. Tekst Bazylego odnosił się jedynie do relacji zachodzących między Osobami Trójcy Świętej i nie miał żadnego związku z problemem ikonoklazmu.

Umieszczanie passusów poza ich właściwymi kontekstami było praktyką budzącą wiele wątpliwości, a mimo to często spotykaną. Każda ze stron konfliktu posługiwała się nią bez większych skrupułów. Uczestnicy II Soboru Nicejskiego oskarżali np. ikonoklastów z 754 r. o wyrywanie cytatów z ich kontekstów, ale sami też tak czynili. Praktyka ta wydaje się usprawiedliwiana pragnieniem ujednolicenia języka teologicznego w ramach tworzenia formalnych stanowisk doktrynalnych. ${ }^{166}$

W wyniku procesu ,selekcji” autorytetów patrystycznych powstawały liczne fałszerstwa i interpolacje tekstów, które miały zaspokoić

${ }^{163}$ Por. I,54.56 - L e o n t i i N e a p o 1 it a n i, Sermo. c. Jud. PG 93, 1601-1608; III,84-89 - t e n ż e, Sermo. c. Jud., PG 93,1597-1601.1605A-1608C; III,72 - S t e f a n z Bosry, Fragm., Studi e Testi 76, s. 205.

${ }_{164}$ I,35 (PG 94, 1261D1264A); III,45 (PG 94, 1361AB).

$165 \mathrm{~Np}$. S. T he o d or i S t u d it a e, Antirrheticus I, 8.20, PG 99, 337AD,349B-351B; Antirrh. II, 24.26.28, PG 99, 368C-369A, 369CD.372A-373A; S. N i c e p h or i, Antirrheticus III, 18.21, PG 100, 401A- 404B,405D-409A.

166 Por. K. P a r r y, Depicting the World, s. 152. 
potrzeby współczesnych dysput. ${ }^{167} \mathrm{Od} \mathrm{V}$ w. odgrywały one coraz większą rolę w szukaniu konsensusu w kwestiach doktrynalnych. Dla Maksyma Wyznawcy nie do pomyślenia było, żeby między Ojcami mogła mieć miejsce jakaś rozbieżność. Był przekonany o pełnym consensus patrum, a wszystkie rodzące się na tym tle wątpliwości należy rozwiązywać przez pogłębione studia ich tekstów. ${ }^{168}$

W takim kontekście problematyczna staje się kwestia pism autorstwa Epifaniusza, biskupa Salaminy (315-403), skierowanych przeciwko twórcom i czcicielom obrazów. ${ }^{169} \mathrm{O}$ ich znaczeniu niech świadczy fakt, że przewodzą one patrystycznemu dossier dołączonemu do horosu z 754 r. Spotkało się to z reakcją II Soboru Nicejskiego, który uznał, że jego pisma ikonoklastyczne są sfałszowane i odrzucone przez Kościół. ${ }^{170}$

Pierwszym ikonofilem, który przedstawiał ikonoklastyczne pisma Epifaniusza jako fałszywe, był Jan Damasceński. Uważał on, że zostały stworzone przez kogoś, kto podawał się za Epifaniusza, co było wówczas praktyką powszechną: „Po pierwsze pismo to może być nieautentyczne i fałszywe - innego bowiem jest autora, a innego nosi podpis - co wielu ma zwyczaj czynić". ${ }^{171}$ Jednak Jan dopuszcza możliwość autentyczności tychże pism. Nawet wtedy nie musi to dowodzić ikonoklastycznej postawy Epifaniusza. Być może chodziło mu tylko o zapobieżenie jakimś nadużyciom związanym z kultem obrazów. Damasceńczyk uzasadnia to w następujący sposób:

167 Tamże, s. 146; por. P.T.R. G r a y, „The Selects Fathers”: Canonizing the Patristic Past, s. 24; R.M. G r a n t, The Appeal to the Early Fathers, s. 14.

${ }^{168}$ K. P a r r y, Depicting the World, s. 146.157; por. J. P e 1 i k a n, The Spirit of Eastern Christendom (600-1700), s. 21. Takim fałszerstwem były np. teksty autora, którego znamy jako Pseudo-Dionizy. Ten anonimowy pisarz z przełomu V i VI w., aby podnieść autorytet swoich wypowiedzi, podawał się za jednego z uczniów św. Pawła - Dionizego Areopagitę, znanego z kart Dziejów Apostolskich.

${ }^{169}$ K. Holl (wyd.), Die Schriften des Epiphanius Genge die Bidverehrung, w: t e n ż e, Gesammelte Aufsätze zur Kirchengeshichte, II 2, Tübingen 1928, s. 351-398.

${ }^{170}$ Mansi, XIII, 293C; por. K. P a r r y, Depicting the World, s. 150.

${ }^{171}$ I,25 PG 94,1257AC; por. II,18 PG 94, 1304C-1305A. 
„...po drugie wiemy, że święty Atanazy sprzeciwiał się wystawianiu w szkatułach ziemskich szczątków świętych, zalecając grzebać je raczej pod ziemią, ${ }^{172}$ chciał w ten sposób znieść odrażający zwyczaj Egipcjan, którzy swoich zmarłych nie chowali pod ziemią, lecz składali na specjalnych łożach lub tapczanach. Być może także wielki Epifaniusz, chcąc zapobiec jakimś nadużyciom, też zabronił sporządzania obrazów - jeśli założymy, że jest on autorem tego pisma". ${ }^{173}$ Ostrze wypowiedzi Epifaniusza zostaje stępione przez fakt, że - co stwierdza Damasceńczyk - jego własny kościół przyozdobiony jest ikonami i było ta aż do czasów współczesnych Janowi. ${ }^{174}$

Ostatni argument, którym posługuje się Jan Damasceński, odnosi się do kwestii consensus patrum. Nie może być ono podważone, kiedy mamy do czynienia ze zdaniem przeciwnym jednego tylko autora: „Po trzecie wreszcie - jeden wyjątek nie może stanowić prawa Kościoła; ani bowiem «jedna jaskółka nie czyni wiosny» (...), ani też pojedynczy głos nie jest w mocy podważyć zgodnej tradycji całego Kościoła, która jest głoszona od krańców po krańce ziemi”. ${ }^{175}$

$$
* * *
$$

Chociaż teologia obrazu i jego obrona św. Jana Damasceńskiego nie w każdym momencie wydaje się stawać na wysokości zadania i nie zawsze w sposób adekwatny odrzuca oskarżenia ikonoklastów, to jednak daje ona solidne podwaliny pod budowę gmachu teologii ikony w okresie drugiego ikonoklazmu, który zakończył się ostatecznie zwycięstwem ikonodulów. Damasceńczyk jako pierwszy

${ }^{172}$ Por. A t a na z y W i e 1 k i, Vita Antonii 90 PG 26, 969A; Św. A t a n a z y A le k s a ndryj s k i, Żywot świętego Antoniego, tłum. Z. B r z o s t k ow s ka, Warszawa 1987, s. 108-109.

173 I, 25.

174 Por. tamże. Nie wiadomo, do którego kościoła odnosi się Jan Damasceński, prawdopodobnie nie był to kościół poświęcony św. Epifaniuszowi w Salaminie Konstancji; por. A.H.S. M e g a w, Byzantine Architecture and Decoration in Cyprus: Metropolita or Provincial? Dumbarton Oaks Papers 28/1974, s. 57-88.

$175 \mathrm{I}, 25$. 
zdefiniował i rozróżnił różne rodzaje kultu, zwracając uwagę na różnicę między czcią oddawaną Bogu, a czcią oddawaną stworzeniom, w tym obrazom; jasno i zdecydowanie rozprawił się z pozornym zakazem tworzenia ikon wynikającym ze Starego Testamentu; wreszcie stworzył pewien kanon posługiwania się argumentami z Tradycji - tak ustnej, jak i z pism Ojców. Jego następcom pozostaje dopracować argument chrystologiczny, oparty na relacyjnej metafizyce Arystotelesa. Stworzona przez Damasceńczyka teologia szeroko rozpowszechniła się we wschodniej duchowości, kształtując silnie zmysł wiary wschodnich chrześcijan.

Piotr FELIGA

Słowa kluczowe: kult obrazów, św. Jan Damasceński, tradition Keywords: Cult of images, St. John of Damascus, Tradition

\section{Defense of the Cult of Images in Three Apologetic Treatises against those Decrying the Holy Images by St. John of Damascus \\ Summary}

St John of Damascus was one of the first theologians who shaped the theology of images. His theology was born in the difficult historical circumstances of the first iconoclasm. This is why it was not always up to the task. But it was John who first defined the image as the object of worship and gave a number of convincing arguments for worshiping them. The basic source of knowledge about the theology of the icon of John of Damascus is his Three Apologetic Treatises against those Decrying the Holy Images. On this basis, I presented the definitions of the cult of images and the various types of worship, then the arguments used by St. John of Damascus in order to validate the worship of images in the context of the Old Testament prohibition on the creation of images and the Christian worship of the saints. Finally, I presented John's theology as an expression of the Church's independence from the emperor's power and his attitude to ecclesiastical tradition, especially to the opinions of the Fathers of the Church. 